\title{
НАДЛЕЖАЩАЯ ОРГАНИЗАЦИЯ СИСТЕМЫ БИОБЕЗОПАСНОСТИ КАК СРЕДСТВО СНИЖЕНИЯ УЯЗВИМОСТИ ОБЩЕСТВА, ЭКОНОМИКИ И ГОСУДАРСТВА ПЕРЕД БИОГЕННЫМИ УГРОЗАМИ
}

\author{
В. А. Гущин ${ }^{1,2} \otimes$, В. А. Мануйлов ${ }^{3}$, В. В. Макаров ${ }^{4}$, А. П. Ткачук ${ }^{3}$ \\ 1 Лаборатория механизмов популяционной изменчивости патогенных микроорганизмов, \\ Национальный исследовательский центр эпидемиологии и микробиологии имени Н. Ф. Гамалеи, Москва \\ 2 Кафедра вирусологии, биологический факультет, Московский государственный университет имени М. В. Ломоносова, Москва \\ 3 Лаборатория трансляционной биомедицины, Национальный исследовательский центр эпидемиологии и микробиологии имени Н. Ф. Гамалеи, Москва \\ Ф ФГБУ Центр стратегического планирования Министерства здравоохранения России, Москва
}

\begin{abstract}
Оценка потенциальной уязвимости общества, экономики и государства перед биогенными угрозами сводится прежде всего к поиску слабых звеньев существующей системы обеспечения биологической безопасности государства. К ним можно отнести как отсутствие отдельных элементов и технических средств мониторинга биологических рисков, так и недостаточность имеющихся аналитических средств для принятия своевременных мер по предупреждению биологических угроз или устранению их последствий. В целом действующие на сегодняшний день в России системы мониторинга биологических угроз достаточно хорошо развиты. Однако их отдельные элементы, во-первых, ведомственно разобщены, что не позволяет создать единую систему с общей координацией, а во-вторых, ни один из них по отдельности не дает результатов, соответствующих всем требованиям, предъявляемым к такой информации. Так, в России действуют, как минимум, четыре отдельные государственные системы сбора информации по эпидемической и эпидемиологической ситуации, которые с должной эффективностью решают узкие задачи по инфекционному мониторингу, но, к сожалению, не способны дополнять друг друга из-за отсутствия единого аналитического центра с доступом ко всем данным. На сегодняшний день отсутствие единого мониторингового центра в области биологической безопасности является фактором потенциально высокой уязвимости общества, экономики и государства перед лицом биогенных угроз. Необходима надлежащая организация современной полнофункциональной и эффективной национальной системы мониторинга биологических угроз как основа для функционирования общенациональной службы обеспечения биологической безопасности и одновременно как средство для идентификации и устранения собственных уязвимых элементов такой государственной структуры.
\end{abstract}

Ключевые слова: биологическая безопасность, мониторинг биологических угроз, патогенные микроорганизмы

Финансирование: статья подготовлена при поддержке Министерства здравоохранения Российской Федерации в рамках программы «Национальная система химической и биологической безопасности 2015-2020" и Министерства образования и науки РФ в рамках проекта RFMEFI60117X0018.

$\triangle$ Для корреспонденции: Владимир Алексеевич Гущин

ул. Гамалеи, д. 18, г. Москва, 123098; wowaniada@gmail.com

Статья получена: 30.09.2018 Статья принята к печати: 14.10 .2018

DOI: $10.24075 /$ vrgmu.2018.054

\section{THE PROPER STRUCTURE OF A BIOSAFETY SYSTEM AS A WAY OF REDUCING THE VULNERABILITY OF A SOCIETY, ECONOMY OR STATE IN THE FACE OF A BIOGENIC THREAT}

\author{
Gushchin VA ${ }^{1,2} \bowtie$, Manuilov VA³ , Makarov W4, Tkachuk AP ${ }^{3}$ \\ Laboratory of Population Variability Mechanisms in Pathogenic Microorganisms, \\ Gamaleya Research Institute of Epidemiology and Microbiology, Moscow \\ 2 Department of Virology, Faculty of Biology, Lomonosov Moscow State University, Moscow \\ ${ }^{3}$ Laboratory of Translational Medicine, Gamaleya Research Institute of Epidemiology and Microbiology, Moscow \\ ${ }^{4}$ Center for Strategic Planning of the Ministry of Health of the Russian Federation, Moscow
}

\begin{abstract}
To understand how vulnerable are a society, an economy and a state in the face of a biohazard, one should attempt to identify any potential holes in the national biosafety system, such as the lack of important components or technologies for biological monitoring and the inadequacy of existing analytical methods used to prevent or counteract biogenic threats. In Russia, biological monitoring is quite advanced. However, the agencies that ensure proper functioning of its components lack collaboration and do not form a well-coordinated network. Each of such agencies alone cannot provide comprehensive information on the subject. In the Russian Federation, there are at least 4 state-funded programs that collect epidemiological data and are quite efficient in performing the narrow task of monitoring infections. But because there is no central database where epidemiological data can be channeled and subsequently shared, these agencies do not complete each other. This leaves the Russian society, economy and state vulnerable to biogenic threats. We need an adequately organized, modern, fully functional and effective system for monitoring biohazards that will serve as a basis for the national biosafety system and also a tool for the identification and elimination of its weaknesses.
\end{abstract}

Keywords: biological safety, biological monitoring, pathogens

Funding: this work was supported by the Ministry of Health of the Russian Federation as part of the project The National System for Chemical and Biological Security of the Russian Federation (2015-2020) and by the Ministry of Education and Science as part of the project RFMEFI60117X0018.

$\square$ Correspondence should be addressed: Vladimir A. Gushchin

Gamalei 18, Moscow, 123098; wowaniada@gmail.com

Received: 30.09.2018 Accepted: 14.10.2018

DOI: $10.24075 /$ brsmu.2018.054 


\section{Необходимость постоянной оценки биологических рисков и угроз}

Термин «биологическая безопасность» охватывает всю сферу санитарно-эпидемиологического состояния, смежные с ней области ветеринарно-санитарного, фитосанитарного контроля, экологической безопасности, среды обитания и используется при мероприятиях по предупреждению и ликвидации чрезвычайных ситуаций (ЧС) биологического характера. Признаком 4С является высокая степень негативного влияния на жизнедеятельность человека, сопоставимая с угрозой национальной и международной безопасности [1, 2]. Здесь уместно дать определение двум основным понятиям, используемым в настоящем обзоре: «биологический (биогенный) риск» - это вероятность причинения вреда (с учетом его тяжести) здоровью человека и/или нанесения ущерба (с учетом его размера) окружающей среде опасными биологическими факторами; «биологическая угроза» определяется как неприемлемый биологический риск [1]. Таким образом, сама по себе биологическая угроза является ЧС.

Биогенные риски, создающие угрозу безопасности в каждой стране и мире в целом, очень разнообразны. Их первопричиной является фундаментальное свойство патогенных биологических агентов (ПБА), т. е. бактерий, вирусов, токсинов, прионов, простейших, проявлять вирулентные свойства по отношению к организму человека, а также к животным и растениям, используемым в сельском хозяйстве. Несмотря на успехи отечественного и мирового здравоохранения, инфекционные заболевания по-прежнему остаются одной из основных причин потери трудоспособности и смертности среди населения. По оценкам экспертов, в 2017 г. экономический ущерб для России только от 32 наиболее актуальных нозологических форм инфекций превысил 627 млрд. руб. [3]. Стоит отметить, что наибольший вклад как в заболеваемость, так и в показатель экономического урона вносят отнюдь не экстраординарные случаи заболеваний особо опасными, «вспышечными», вновь возникающими или завезенными инфекциями, а традиционные сезонные, эндемичные для России ОРВИ, грипп, туберкулез, острые кишечные инфекции, ветряная оспа, ВИЧ-инфекция и вирусные гепатиты [3].

Способы контроля за инфекционными заболеваниями хорошо известны и широко применяются: вакцинопрофилактика, внедрение средств своевременной этиологической диагностики, применение специфических противовирусных и антибактериальных препаратов, повышение уровня общей гигиены и медицинской асептики, противодействие основным негативным эпидемиологическим факторам, в конце концов - повышение социальноэкономического благополучия общества в целом [4]. Однако из-за самой биологической природы инфекций эффективность перечисленных способов быстро снижается со временем в результате эволюции возбудителей, избегающих этих новых факторов естественного отбора [5]. Следствием снижения этой эфффективности являются такие общеизвестные процессы, как регулярная смена штаммов (серотипов, генотипов) возбудителей сезонных и/или эпидемических респираторных и алиментарных заболеваний; схожесть нозологических и эпидемиологических процессов, вызываемых возбудителями различных таксонов (и, соответственно, по разному восприимчивых к средствам профилактики, диагностики и терапии); появление и распространение мутантных штаммов возбудителей, способных преодолевать барьеры иммунизации и диагностический контроль; появление мутантных штаммов, устойчивых к действию специсических терапевтических препаратов, появление новых ПБА, ранее не циркулировавших в человеческой популяции, проникающих из природных резервуаров инфекции. Динамичные изменения в структуре циркулирующих ПБА накладываются на нередко резко выраженную неоднородность эфрфективности вакцинации и доступности диагностических и терапевтических средств в различных географических, возрастных и социальных группах населения. Все эти фракторы инфекционных процессов необходимо всесторонне и своевременно отслеживать для предотвращения эпидемического характера распространения ПБА (т. е. трансформации биологического риска в реальную угрозу) [6]. Для этого органам государственного здравоохранения и надзора безусловно необходимо иметь в своем распоряжении максимально эсффективный организационный инструмент для изучения существующей инфекционной ситуации в стране и прогнозирования направлений ее развития.

Необходимость организации единой системы мониторинга биологических рисков в целях предотвращения биологических угроз прямо определена в программных документах Правительства РФ и действующих нормативно-правовых актах на уровне Федерального законодательства [1, 7-9]. В частности, «Основы государственной политики в области обеспечения химической и биологической безопасности Российской Федерации на период до 2025 года и дальнейшую перспективу» [8] определяют в качестве приоритетных направлений и задач государственной политики мониторинг биологических рисков, а также развитие ресурсного обеспечения соответствующих функциональных элементов национальной системы биологической безопасности РФ. В «Стратегии национальной безопасности Российской Федерации", опубликованной в конце 2015 г. [9], органам государственной власти и органам местного самоуправления во взаимодействии с институтами гражданского общества, предписывается развитие системы мониторинга биологической обстановки на территории Российской Федерации.

Авторы настоящей статьи считают необходимым дать рекомендации, касающиеся организации единого координирующего центра межведомственного взаимодействия [10], с тем чтобы не допустить дублирования существующих сегодня систем отчечественного эпидемиологического надзора, поскольку, как отмечалось выше, уязвимости в системе биологической безопасности могут быть прямо приравнены к уязвимостям всего государства и общества.

\section{Отсутствие единой системы мониторинга биологических угроз}

На сегодняшний день в Российской Федерации на уровне государства используются четыре основных способа сбора эпидемической и эпидемиологической информации. Они применяются для решения частного круга задач по общему инфекционному мониторингу:

- анализа заболеваемости населения наиболее распространенными нозологическими формами инфекций;

- расследования вспышек заболеваний;

- контроля инфекционной опасности объектов окружающей среды и товаров народного потребления; 
- изучения локальной встречаемости социальнозначимых инфекций и действия эпидемиологических факторов в группах риска;

- изучения и прогнозирования смены сезонных и периодических штаммов некоторых эпидемических инфекций.

Рассмотрим эти способы по отдельности.

1. Анализ заболеваемости распространенными формами инфекций осуществляется Роспотребнадзором [11]. Информация собирается на уровне региональных и муниципальных лечебно-профилактических учреждений (ЛПУ). Ставя диагноз инфекционного заболевания, врач информирует об этом региональный центр Роспотребнадзора путем заполнения форм государственной статистической отчетности [12]. Сбор, обработка и публикация статистических данных осуществляется Роспотребнадзором ежегодно.

Несомненными достоинствами такого способа сбора информации являются: широкий охват населения во всех регионах - фактически учитывается встречаемость ПБА у всех обратившихся к врачам пациентов; устойчивость такой системы мониторинга, обеспечивающая распределенность и непрерывность исследований и связанная с большим количеством задействованных ЛПУ; однородность предоставляемых данных, обеспечиваемая единообразием форм документации.

В то же время, особенность данного вида учета связана с самим определением показателя заболеваемости, рассчитываемого как отношение числа больных с впервые установленным диагнозом к среднегодовой численности населения [13], т. е. регистрируется количество только официально выявленных случаев инфицирования среди самостоятельно обратившихся пациентов. Остаются неучтенными люди, страдающие неманифестными хроническими формами заболевания, не пожелавшие обратиться к врачу, или с неправильно установленным диагнозом, но при этом являющиеся распространителями инфекции. Это приводит к нерелевантности обследуемой группы, не позволяющей достоверно оценить распространенность инфекции в общей популяции. Также отметим, что в большинстве случаев сотрудники ЛПУ не располагают технологической базой для тонкой расшифровки этиологии ПБА, особенно в отношении респираторных и острых кишечных заболеваний. Совершенно разные в этиологическом, эпидемиологическом и биологическом отношении инфекции, требующие специальных средств профилактики и лечения, учитываются одинаковым образом, т. е. недостоверно.

Сбор и анализ статистических данных, поступающих из ЛПУ, позволяет постфактум оценивать многолетнюю динамику заболеваемости, и строить тренды для этого показателя. Однако такой метод является косвенным (не дает достоверной информации о реальной встречаемости инфекций в популяции, т. е. величине инфекционного резервуара и уязвимости общества перед ним), имеет низкое разрешение в отношении этиологии возбудителей, и не обладает предиктивной силой, особенно в отношении редких и вновь возникающих инфекций.

Анализ документальной прививаемости населения также осуществляется Роспотребнадзором на основе статистических форм, предоставляемых региональными ЛПУ. Прививаемость не является прямым показателем эпидемических процессов, но используется как один из важнейших параметров в моделировании развития инфекционной ситуации. Показано, что документальная прививаемость не может служить этим целям, и что для надежного прогнозирования эпидемических процессов этот показатель должен быть уточнен путем прямого сероэпидемиологического измерения уровня популяционного иммунитета к вакциноуправляемым и ряду других инфекций [6].

2. Государственный санитарно-эпидемиологический надзор [14] осуществляется региональными и федеральным Центрами гигиены и эпидемиологии (ЦГиЭ) Роспотребнадзора $[11,15]$. В основную сферу их деятельности в отношении инфекций входят плановые и внеплановые проверки объектов окружающей среды (воды, товарной продукции, земельного фонда и т. д.) на наличие ПБА из утвержденного списка, большая часть которых относится к возбудителям природно-очаговых инфекций, острых кишечных инфекций и гельминтозам [16-18], а также расследования в отношении вспышек инфекций [13].

Аналогичные функции, но в отношении ветеринарных инфекций, в том числе опасных для человека, возложены на межобластные и региональные ветеринарные лаборатории Россельхознадзора, также осуществляющие задачи инфекционного мониторинга. Однако имеющаяся в Россельхознадзоре информация не поступает в органы здравоохранения и не учитывается ими.

Надзорные функции в отношении ПБА выполняются системой ЦГиЭ в значительной мере эффективно, что обусловлено развитой региональной лабораторной сетью и оснащением ее современным высокотехнологичным оборудованием и тест-системами. Это обеспечивает непрерывность проведения планового мониторинга инфекций, возможность установления точной этиологии ПБА, а также способность оперативно фиксировать появление неэндемичных ПБА и возбудителей эпидемических, особенно опасных и/или природноочаговых инфекций и расследовать их распространение при вспьшках.

В то же время, регламентированные рутинные функции Роспотребнадзора в отношении мониторинга инфекций ограничены достаточно узким перечнем ПБА [16, 17], методов их идентификации [18] и спектром типовых объектов исследования, что не позволяет определить реальную встречаемость инфекций (даже профильных) среди населения страны, а соответственно уязвимость перед ними в масштабе государства.

Исполнительные органы Роспотребнадзора располагают значительным опытом и инструментарием для детекции возбудителей алиментарных, зоонозных и природноочаговых инфекций и расследования вызываемых ими вспышек заболеваний, но практически не участвуют в контроле парентеральных и эпидемических респираторных инфекций, хотя экономический и социальный ущерб от последних кратно выше, чем ущерб от относительно редких для России вспышечных инфекций [3].

В целом, можно заключить, что существующая система государственного санитарно-эпидемиологического надзора успешно решает важные, но узкоспециализированные практические задачи, только отчасти релевантные инфекционному мониторингу населения страны в широком смысле.

3. Научно-исследовательский эпидемиологический мониторинг в отношении ограниченного спектра ПБА в отдельных группах населения или географических областях периодически осуществляется государственными научными учреждениями Роспотребнадзора, Минздрава 


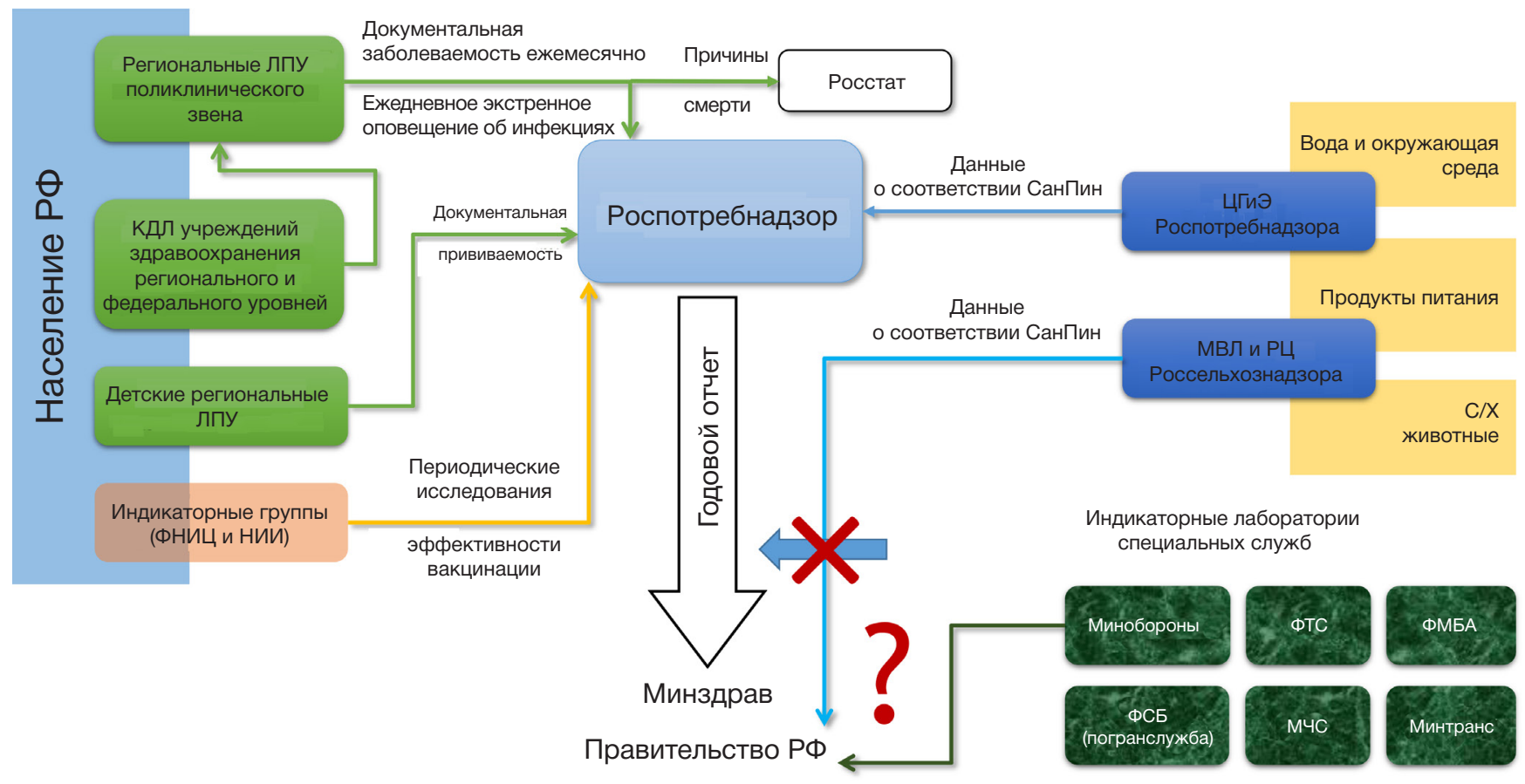

Рис. 1. Современная схема мониторинга биологических угроз

и Минобрнауки РФ. Такие исследования проводятся в рамках выполнения государственных заданий (ранее - фредеральных целевых программ), или в инициативном порядке в соответствии с собственными научными планами и финансовыми возможностями. Как правило, научные учреждения не имеют прямо поставленной ведомственной задачи осуществлять постоянный мониторинг инфекций в статистических целях, но некоторые из них приобрели статус центров по контролю за определенными видами ПБА (например, Федеральный научно-методический центр СПИД на базе ЦНИИ Эпидемиологии, сотрудничающий центр ВОЗ по гриппу на базе ГНЦ ВБ «Вектор», или Национальный научно-методический центр по надзору за корью в МНИИЭМ им. Г. Н. Габричевского) и располагают соответствующими референтными лабораториями для диагностических исследований. Именно от таких научных центров поступает, например, информация о сезонных циркулирующих штаммах и серотипах некоторых ПБА (в частности, вируса гриппа), что имеет важное значение для профилактики.

Работы в таких центрах, как правило, выполняются на высоком научно-технологическом уровне, что обеспечивает значительную чувствительность и специфичность в отношении диагностики и установления этиологии различных ПБА, а также соответствуют надлежащим правилам эпидемиологической науки. В результате определяется реальная встречаемость ПБА в той или иной группе риска среди условно здорового населения или в выбранной референтной группе, что обеспечивает высокую степень достоверности такой информации.

Однако нельзя не отметить, что научные учреждения в основном выполняют подобные исследования локально, с нерегулируемой периодичностью (что связано с особенностями их финансирования) и в отношении только «Профильных» для них ПБА. Таким образом, в данном случае тоже нельзяговорить о непрерывности илишироком охвате этих эпидемиологических исследований. Кроме того, здесь сложно судить о единой системе мониторинга, так как результаты исследований предоставляются в свободном виде (как правило, в форме научных статей в разных источниках и/или отчетов), что не позволяет интегрировать их с имеющейся медицинской статистикой, особенно с учетом ведомственной разобщенности задействованных научных учреждений.

4. Медико-санитарные ведомственные службы также собирают данные о заболеваемости в той или иной группе населения (и о заражении отдельных объектов окружающей среды). К ним относятся специализированные части Федеральной службы безопасности, Министерства обороны, Федеральной таможенной службы, Федеральное медико-биологическое агентство (ФМБА), Министерство чрезвычайных ситуаций (МЧС), Министерства транспорта и пр. Однако собираемая ими информация предназначена исключительно для внутреннего использования и, по данным авторов настоящей статьи, никак не учитывается в деятельности гражданского здравоохранения. Таким образом, перечисленные структуры (по крайней мере, в мирное время), никак не участвуют в общегосударственном мониторинге инфекционных процессов.

Обобщая, можно заключить, что существующие в современной России элементы системы мониторинга инфекционных заболеваний достаточно хорошо развиты (рис. 1), однако, во-первых, не позволяют объединить усилия в этой области из-за различной ведомственной принадлежности исполнителей, а во-вторых, ни одна из них по отдельности не соответствует всем критериям количества и качества предоставляемой информации (релевантности по отношению ко всему населению, этиологической детализации и оперативности информации). Самая же большая проблема заключается в том, что все описанные способы не являются взаимодополняющими из-за отсутствия единого аналитического центра с доступом ко всем данным. 
В этой связи создание единого центра мониторинга позволит преодолеть указанные недостатки при соблюдении нужных принципов осуществления мониторинга [10]. При этом такой центр не должен дублировать функции перечисленных ведомств (такие как анализ заболеваемости, расследование вспышек и анализ безопасности продукции, научные эпидемиологические исследования в группах риска). Создаваемая система должна напрямую измерять параметры распространенности ПБА у населения, их типов и серологических маркеров к ним в целях решения поставленных задач по снижению уязвимости общества, экономики и государства перед биогенными угрозами.

Работа мониторингового центра должна организационно и функционально дополнять действующую систему реагирования на чрезвычайные ситуации медикобиологического характера и повышать ее эффективность за счет значительного сокращения времени реагирования на чрезвычайные ситуации. Схема мониторинга биологических рисков в представлении авторов предложена на рис. 2.

В то же время, эффективная работа по обеспечению национальной биологической безопасности должна учитывать не только организационные моменты по взаимодействию между различными надзорными органами и интеграцию данных различных систем сбора информации. Уязвимость общества перед биологическими угрозами во многом определяется и иными, фундаментальными свойствами как самих ПБА, так и способов их индикации.

Влияние человеческого фактора на проведение анализов. Медленная скорость проведения индикации патогенных биологических агентов

Интеграция существующих источников информации об имеющихся биологических рисках в динамическом режиме в рамках единого центра позволит существенно ускорить время реакции на появление биологических угроз. Между тем, самостоятельной угрозой является то, что существующих источников информации для оперативного мониторинга недостаточно, либо они не в полной мере отвечают требованиям специфичности, чувствительности, оперативности, автономности, автоматической работы. В частности, время реакции на информацию о потенциально угрожающем биологическом событии, получаемой от обычной клинико-диагностической лаборатории ЛПУ или Центра гигиены и эпидемиологии (даже хорошо оснащенной) оказывается недопустимо большим - если учесть, что в него включено не только время, затрачиваемое на само проведение исследования, передачу данных и принятие решения, но и время, которое требуется носителю инфекции, чтобы осознать наличие заболевания (т. е. весь инкубационный период), обратиться к врачу, сдать анализ и т. д.

Поэтому перспективная система мониторинга биогенных рисков должна быть основана не только на агрегации лабораторных данных, получаемых от КДЛ, но и на основе создания собственной сети источников информации о биологических рисках, включающей автоматизированные средства индикации ПБА в режиме «реального времени» [19].

Прогресс в области лабораторной диагностики биопатогенов дает возможность создавать наряду с традиционными методами, требующими участия квалифицированного персонала, экспресс-методики с минимальной долей ручного труда оператора и автоматизированные комплексы, работающие без участия человека [19]. При сохранении чувствительности и специфичности, новые подходы сокращают время проведения анализа от суток до часов и минут.

\section{Мониторинг биологических угроз: перспективная схема}

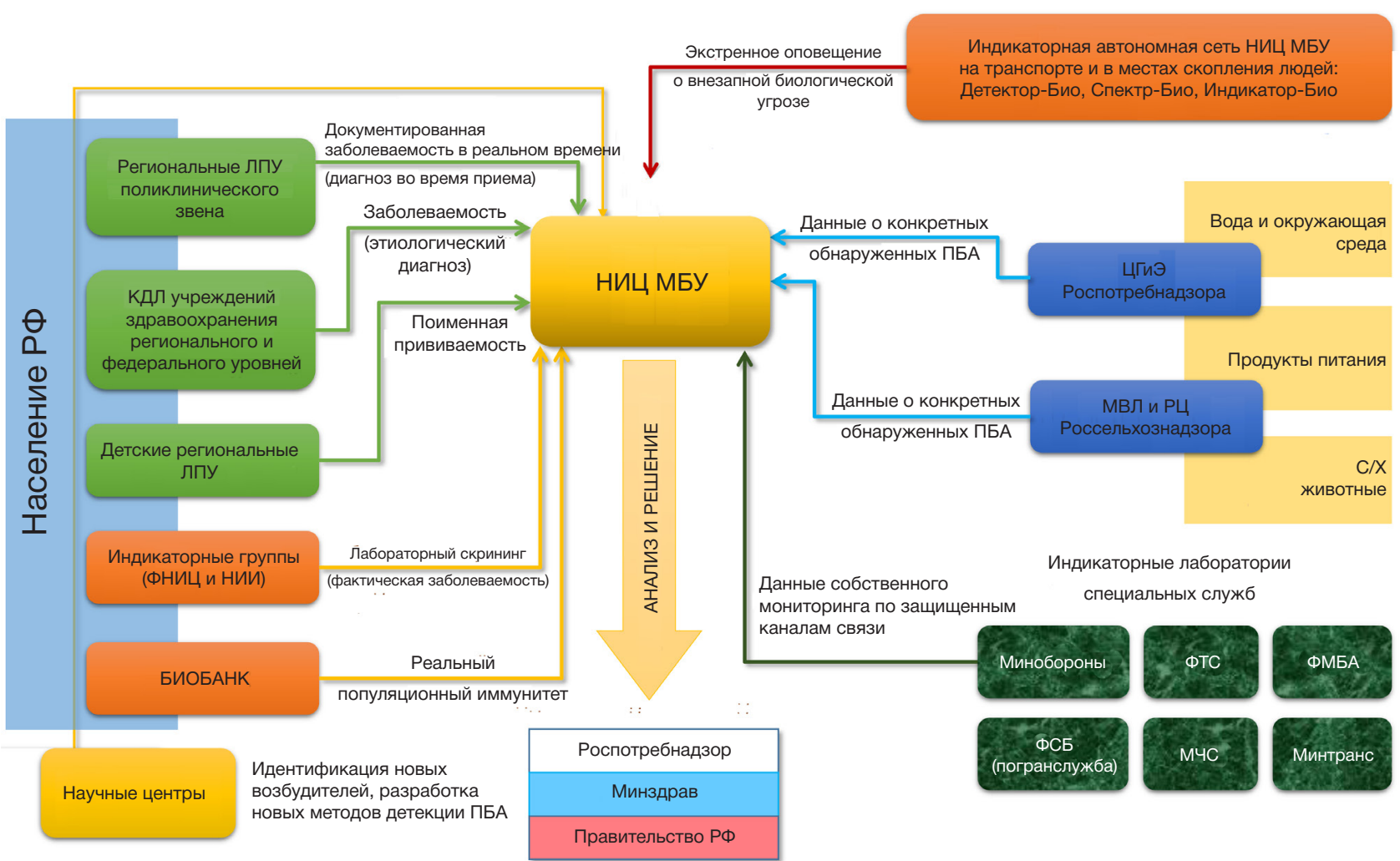

Рис. 2. Мониторинг биологических угроз при условии наличия единого Научно-исследовательского центра мониторинга биологических угроз (НИЦ МБУ) 
Автоматизированные комплексы в автономном исполнении могут анализировать образцы окружающей среды на наличие патогенов практически непрерывно.

Прямой анализ воздушного аэрозоля позволяет выявить возбудителей инфекционных заболеваний до момента заражения индивидуумов, что с учетом латентного периода может сократить время ранней диагностики на несколько суток, а в случае своевременного принятия мер решительно сократить число людей, подвергшихся заражению. Сэкономленное время можно использовать для развертывания массовой вакцинации или превентивной терапии (введение иммуноглобулинов) среди населения.

На сегодняшний день очевидно, что для автоматической детекции широкого спектра биопатогенов в окружающей среде - бактерий, вирусов, токсинов - наиболее надежным видится применение иммунологического анализа и анализа нуклеиновых кислот [19]. Первый обеспечивает обнаружение не только клеточных и внеклеточных фрорм ПБА, но и продуктов их жизнедеятельности. Второй более чувствителен при анализе малого количества исходного материала [19]. Одновременная детекция двумя методами существенно снижает риск ложноположительных результатов $[19,20]$, а возможность количественного определения аналита повышает информативность индикаторного теста.

В то же время требование автономности работы приборов в полностью автоматическом режиме в течение длительного времени накладывает ограничения на применяемые методики. Они должны содержать минимальное количество стадий, сохранять приемлемую чувствительность (не менее 1000 инфекционных частиц патогена/мл аэрозольного концентрата) и специфичность в сочетании с экспресс-пробоподготовкой, обеспечивать максимально короткое время анализа. Сфера применения автоматических комплексов детекции биопатогенов в воздухе и требование мобильности налагает ограничения на их внешние размеры. Используемые системы автоматизации методов детекции должны иметь минимальные размеры, выдерживать транспортировку без необходимости дополнительного технического тестирования, обеспечивать длительную бесперебойную работу в неблагоприятных внешних условиях, поддерживать герметичность соединений для исключения кросс-контаминации и загрязнения внутреннего объема прибора. Обслуживание прибора, удаление отработанных материалов должны обеспечивать безопасность персонала.

Несмотря на очевидную необходимость контроля аэрозоля на наличие возбудителей инфекционных заболеваний или токсинов, реальное применение автоматического прибора анализа биоаэрозоля будет сильно зависеть от возможностей самого устройства: скорости анализа, чувствительности и специфичности, возможности количественного определения концентрации патогена в воздухе, стоимости устройства, расходных материалов и обслуживания, количества одновременно определяемых патогенов, а также спектра разработанных тест-систем [6, 21, 22]. Все перечисленное должно быть учтено при развертывании сети автоматических средств индикации создаваемого единого центра мониторинга биологических угроз.

ION S5

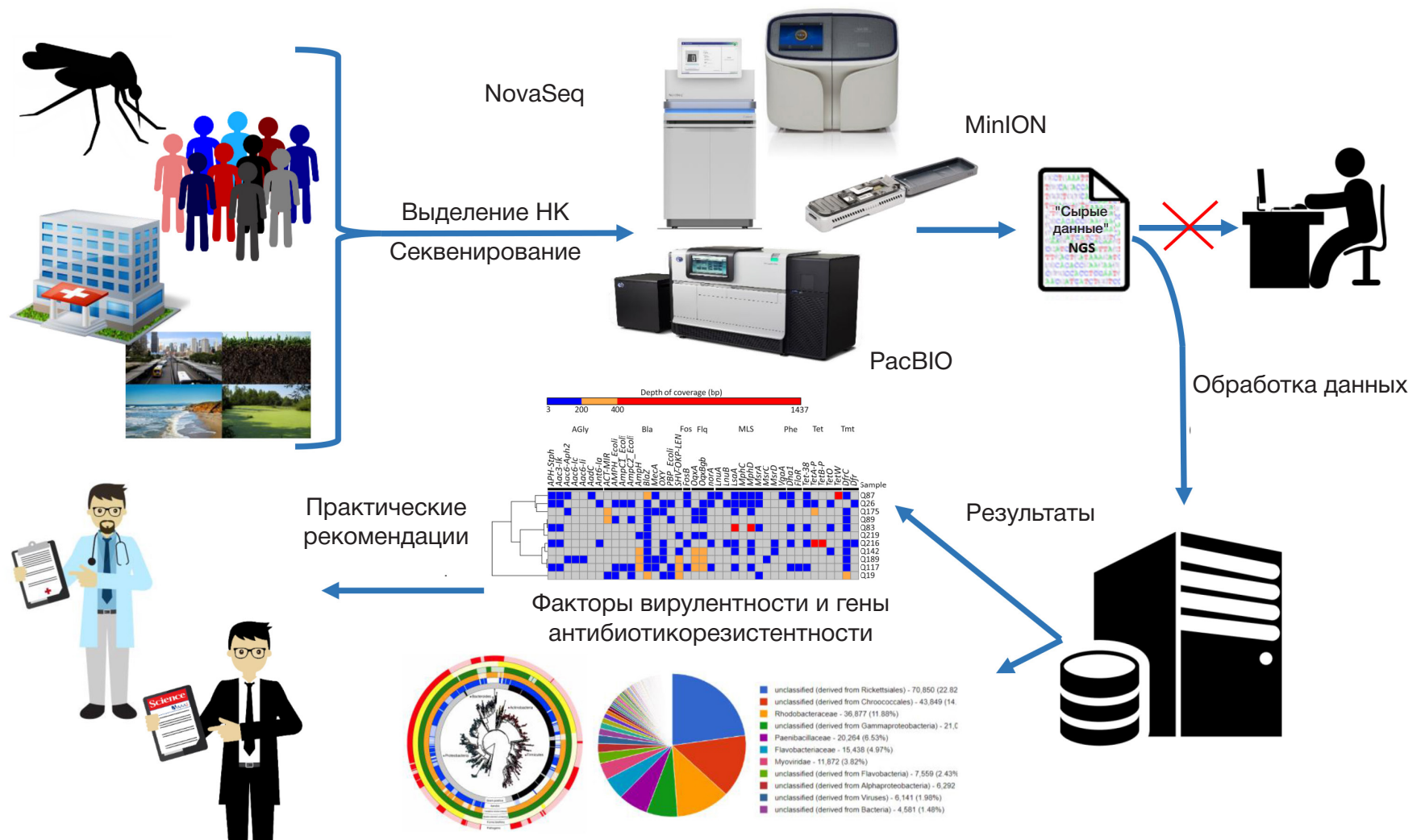

Идентификация бактерий, вирусов с предсказанием значимости

Рис. 3. Алгоритм идентификации новых патогенов, факторов вирулентности и антибиотикорезистентности бактериальных патогенов. НК — нуклеиновые кислоты 
Проблема идентификации ранее неизвестных патогенов и патогенов с новыми свойствами

Как уже отмечалось выше, в последние годы быстро растет количество бактерий с лекарственной устойчивостью, в разных регионах мира регулярно детектируются возбудители новых инфекционных заболеваний, а риск применения биологического оружия, в том числе в рамках биотеррористических акций остается достаточно высоким. В связи с этим возрастает актуальность разработки и использования новых технологий идентификации неизвестных патогенов, в том числе с новыми не описанными свойствами.

Использование микробиологами и врачамиинфекционистами платформ высокопроизводительного секвенирования обеспечило значительный прогресс в медицинской сфере. Благодаря широкому распространению коммерчески доступных платформ секвенирования нового поколения (NGS), таких как Miseq and Hiseq (Illumina), GS (Roche-454), lon Torrent (Life Technologies), Minion (Oxford Nanopore Technologies) и PacBio (Pacific Biosciences), определение последовательностей геномов ПБА (или их регионов) внесло значительный вклад в клиническую микробиологию и вирусологию, позволяя создавать различные диагностические инструменты на их основе [23]. Помимо этого, обеспечивая доступ к полному набору генов различных штаммов, NGS дает уникальную возможность определения потенциала вирулентности и предсказания антибиотикорезистентности обнаруженных изолятов. Идентификация и характеристика факторов вирулентности, особенно токсинов и маркеров антибиотикорезистентности патогенов необходимы для понимания патогенеза заболеваний, вызываемых бактериями, и их взаимодействия с организмомхозяином, а также для разработки новых лекарственных средств, вакцин и тестов для молекулярной диагностики $[10,24]$.

Возможность использования метода секвенирования следующего поколения в микробиологии и эпидемиологии открывает совершенно новые горизонты для определения новых патогенов и глубокого изучения их свойств (рис. 3).

Методы NGS на данный момент уже применяются в некоторых медицинских микробиологических лабораториях, включая, например, лабораторию в University Medical Center Groningen (UMCG), где они используются для контроля над развитием вспышек инфекций, молекулярноэпидемиологических исследований, характеристики патогенов и наблюдения за ними, быстрой идентисикации бактерий с использованием области PPHK 16S-23S, таксономии, для метагеномных подходов к клиническим образцам и для определения передачи зоонозных инфекций от животных к людям

Преимущество использования полногеномного секвенирования (whole genome sequencing, WGS) в том, что оно обеспечивает внедрение NGS в эпидемиологические исследования и исследования общественного здоровья [25-26]. Помимо отслеживания вспьшек и их характеристики, использование WGS позволяет также предпринимать контрольные меры против распространения резистентных бактериальных клонов. Например, вспышка заболевания, вызванная колистин-резистентными продуцирующими карбапенемазы бактериями K. pneumonia, распространившаяся между несколькими клиниками в Нидерландах, контролировалась путем направления всех носителей резистентного штамма в отдельное медицинское учреждение, где специализированная команда лечила этих пациентов [27].

Помимо детекции бактерий с множественной лекарственной устойчивостью, методика WGS также эффективна для характеристики высоковирулентных бактерий, таких как шигатоксин-продуцирующая Escherichia coli (shigatoxin-producing Escherichia coli, STEC) 0104:H4, вызвавшая вспышку заболевания в Германии в 2011 г. [28].

Молекулярная идентификация возбудителей часто используется в исследовании вспышек инфекций. Базы данных NGS и WGS могут быть ретроспективно проанализированы в случае вспышек, вызванных несколькими возбудителями. Результатом этого может быть определение возбудителей, которые не были идентифицированы в ходе эпидемиологических исследований, основанных на использовании ПЦР или серологических методов [29-30].

Текущая рутинная процедура характеристики патогенов основывается на большом спектре бактериологических, биохимических и молекулярных методов, что делает ее трудоемкой, требующей временных затрат и дорогостоящей. NGS может служить надежным односложным инструментом для исследования широкого спектра свойств патогенов, применимым к большому диапазону патогенов [31-33]. Знание профиля вирулентности патогена имеет решающее значение для прогнозирования тяжести заболевания, результатов лечения и для оценки риска в случае раннего начала заболевания. WGS может внести существенный вклад в определение наличия факторов вирулентности с использованием нескольких онлайн-инструментов, поскольку он не ограничивается специсрическим геном [34, 35].

В одном из больших когортных исследований метод WGS использовали для молекулярной характеристики STEC, что давало четкое представление о структуре популяции и геномной пластичности этого штамма в городах Гронинген и Роттердам (Нидерланды) [36]. Вся релевантная информация может быть извлечена in silico из баз данных по сиквенсам, включая генотип, серотип, данные мультилокусного секвенирования, просили вирулентности и антибиотикорезистентности и филогенетические данные для получения общих молекулярных признаков с высокой степенью селективности среди близкородственных штаммов. Метод NGS позволил подробно описать и сравнить многие штаммы в течение относительно короткого промежутка времени. Таким образом, для быстрого и оптимального молекулярно-эпидемиологического надзора за патогенами в региональном и национальном масштабах роль WGS неоспорима. Метод NGS эффективен также для выявления новых генов резистентности как у ныне существующих бактерий, так и у исторических штаммов. Новые варианты генов антибиотикорезистентности можно идентифицировать с использованием NGS, a дальнейшие эксперименты помогут определить, действительно ли эти гены отвечают за наблюдаемый паттерн антибиотикорезистентности [37].

NGS позволяет осуществить детекцию теоретически неисчислимого количества патогенов без использования культур и вследствие этого способствует пониманию полного микробиома. Метагеномика, по мнению некоторых авторов, будет итоговым подходом к детекции всех микроорганизмов [38]. Однако для анализа больших объемов данных требуется сочетание биоинформационных и вычислительных ресурсов, которые в настоящее время по большей части отсутствуют в диагностических 
медицинских микробиологических лабораториях. Кроме того, метагеномные подходы требуют много времени, так как время выполнения анализа составляет около 4-5 дней.

Чтобы заполнить пробел между общепринятыми методами по обнаружению и идентификации видов микроорганизмов (культуральными микробиологическими и ПЦР) и метагеномикой, представляется перспективным подход, основанный на таргетном NGS без высева культуры (рис. 3). По сравнению с метагеномикой он быстрее, дешевле и проще методологически, в связи с чем, вероятно, в обозримом будущем займет достойное место в арсенале рутинных диагностических лабораторий. Было доказано, что последовательность гена 16S PPHK является надежным генетическим маркером идентификации бактерий на уровне рода (в ряде случаев вида и даже штамма), поскольку он присутствует у всех бактерий и его функция неизменна [39]. Секвенирование последовательности гена может быть выполнено непосредственно из клинического материала (без наращивания чистой культуры) и, вследствие этого, идентификация спектра бактерий по последовательности $16 \mathrm{~S}$ рPHK уже сейчас является ценным дополнительным тестом в повседневной клинической практике $[40,41]$. Однако выраженное сходство в последовательностях гена между определенными видами бактерий может приводить к неоднозначной идентификации [42].

Недавно был разработан инновационный подход NGS 16S-23S pPHK без использования культур для детекции бактерий в клинических образцах. Метод показал ряд преимуществ по сравнению с аналогичными способами анализа. Он корректно идентифицирует патогены, определенные как причина инфекции, культуральным методом в образцах мочи [43]. Более того, метод позволяет осуществить одновременную идентификацию нескольких патогенов в биологическом материале, в котором ранее ни культуральным методом, ни методом ПЦР возбудитель не выявлялся. Несомненно, такой новый подход внесет значимый клинический вклад в развитие микробиологии, а также повлияет на тактику лечения пациентов, оптимизируя антибиотикотерапию. Наконец, этот метод позволит клиническим микробиологическим лабораториям внедрить NGS в рутинную практику и будет способствовать развитию технологического и биоинформационного обеспечения, необходимого для внедрения метагеномики в диагностику заболеваний в будущем.

В самом деле, использование WGS в таксономических целях позволяет включить больше генов для разграничения видов, чем классическая ДНК-ДНК-гибридизация или методы секвенирования $16 \mathrm{~S}$ рPHК, тем самым повышая разрешающую способность. Более того, поскольку WGS можно использоваться для филогенетической реконструкции на основе последовательностей всех генов, присутствующих в геноме, соответствующая генетическая дендрограмма может быть воспроизведена более отчетливо [44]. Высказывались предположения о том, что описания новых таксонов должны также включать геномные последовательности по меньшей мере с двадцатикратным повторным прочтением [45].

NGS в будущем позволит получить также больше информации О зоонозной передаче ПБА. Первые исследования по этой теме были основаны на методах с низкой селективностью, таких как серотипирование [46]. Совсем недавно опубликованы работы, в которых более селективные методы, такие как электрофрорез в импульсном поле или мультилокусный анализ областей генома с вариабельным числом тандемных повторов, были использованы для обнаружения специфических бактериальных клонов у животных и людей [47]. Многие аспекты биологических механизмов зоонозного распространения инфекций еще нуждаются в уточнении, особенно когда речь идет о частоте передачи (например, единичный или повторный контакт с животными или продуктами животного происхождения), факторах риска, ассоциированных с заражением зоонозным микроорганизмом (например, потенциально опасные действия, такие как близкое взаимодействие с животными или обработка стула сельскохозяйственных животных) и о том, как использование антибиотиков у животных влияет на передачу патогенных бактерий людям. NGS открывает новые перспективы для изучения этих аспектов. Высокая селективность метода позволит дифференцировать ранее не различимые бактериальные штаммы, поражающие животных и человека. Это, вкупе с эпидемиологической информацией, позволит детализировать источники потенциальных зоонозных инфекций [47-48].

Таким образом, можно отметить, что использование метагеномного подхода и NGS позволяет провести комплексный анализ патогена, включая изучение профиля антибиотикорезистентности, продукции токсинов, а также других факторов патогенеза, способности к межвидовой передачи данных фракторов. Между тем, несмотря на высокий потенциал использования метагеномного анализа и NGS в составе систем идентификации ранее неизвестных патогенов и патогенов с новыми свойствами, применение этих методов в клинической практике ограничено единичными случаями.

\section{Появление новых патогенных биологических агентов или новых патогенных свойств}

Вспышки инфекционных заболеваний создают постоянную угрозу для населения. Большое внимание уделяется появлению относительно новых или неизвестных патогенов, например, ближневосточного респираторного коронавирусного синдрома и вируса Эболы в Заире. Однако значительно чаще эпидемии вызывают известные патогены, такие как вирус гриппа, денге, возбудитель туберкулеза или холерный вибрион. Большинство эпидемий возникает из-за внешних, климатических или географических факторов. Однако иногда их причиной становится антропогенное воздействие. Фактически каждые несколько лет возникает новая опасность, вызванная появлением и распространением новых патогенных организмов. В литературе описаны фракты появления новых инфекционных агентов в 21 веке [49]. Яркими примерами антропогенного влияния человека на появление новых ПБА (или приобретение ими новых свойств) являются распространение антибиотикорезистентных штаммов и модификация ПБА в целях биотерроризма.

Антибиотикорезистентность возбудителей инфекционных заболеваний человека

Резистентность патогенных микроорганизмов $\mathrm{k}$ антимикробным препаратам, в том числе множественная, широко распространена и является важнейшим фактором снижения эффективности лечения инфекционных заболеваний почти во всех регионах мира. ВОЗ определяет эту проблему 
как «угрозу национальной безопасности многих стран». Актуальность угрозы, исходящей от распространения антибиотикорезистентных микроорганизмов для России, отмечена в ряде работ [50-60].

Открытие и применение ряда антибиотиков с конца 1930-х годов спасло жизни миллионов людей от острых бактериальных инфекций. Так, пенициллин G стал «магической пулей», препаратом, принципиально сократившим смертность во время второй мировой войны от стрептококковой инфекции. К тому времени, когда появились первые резистентные к пенициллину штаммы, были разработаны антибиотики второго поколения, такие как метициллин, цефалотин, имипенем. Но уже в 1961 г. был выделен метициллинрезистентный штамм золотистого стафилококка, MRSA. Вскоре стали идентифицировать клинические штаммы, устойчивые к стрептомицину, хлорамфениколу и тетрациклину. В дальнейшем на основании опыта, накопленного с начала эры антибиотиков, стало очевидным, что устойчивость формируется ко всем известным антибактериальным препаратам. Практически для всех антибиотиков после начала клинического применения резистентность развивается фактически за 1-2 года. Это привело к тому, что многие фармацевтические компании замедлили или прекратили программы по разработке новых антибиотиков, поскольку такие препараты стало сложнее коммерциализовать из-за их низкой эффективности. Так, с 1987 г. не было открыто ни одного нового класса антибиотиков, и на сегодняшний день разрабатывается слишком мало антибактериальных препаратов, чтобы решить проблему множественной лекарственной устойчивости [61]. Достижения мирового здравоохранения находятся под угрозой, так как глобально распространяющаяся резистентность К противомикробным препаратам не обеспечивает защиту пациентов от потенциально смертельных болезней и не позволяет проводить с наименьшим риском такие жизненно важные процедуры, как хирургические операции и химиотерапию [62-65].

Распространение резистентности К антибиотикам в первую очередь обусловлено возрастающим неконтролируемым приемом, а также нерациональным их использованием. По данным мировой статистики примерно в 75\% случаев назначение антибактериальных препаратов неоправданно [64]. Монорезистентные штаммы микроорганизмов постепенно становятся полирезистентными, затем и панрезистентными. Появилось понятие «проблемных» микроорганизмов. Это микроорганизмы, среди которых наиболее часто, особенно в условиях стационара, где широко применяются антибактериальные препараты и дезинфектанты, встречаются штаммы, резистентные ко многим, а иногда и ко всем известным противомикробным средствам. K таким проблемным микроорганизмам относятся золотистый стафилококк, синегнойная палочка, клебсиелла, энтерококки, пневмококки и др. [66].

Формирующаяся генетически детерминированная устойчивость связана с целым рядом хорошо изученных механизмов, среди которых инактивация антибиотика, модификация мишени действия, приобретение или увеличение активности молекулярных помп для выведения антибиотика из микробной клетки, нарушение проницаемости внешних структур микробной клетки, формирование метаболического «шунта» [67]. Эти знания дают возможность детектировать резистентные микроорганизмы непосредственно, методом ПЦР или секвенирования, без высева на средах, содержащих антибиотики и даже без идентификации видовой принадлежности бактерии (поскольку гены устойчивости к антибиотикам часто передаются горизонтально даже между представителями разных таксонов). Таким образом, имеется технологическая возможность (и необходимость) детектировать распространение антибиотикорезистентных штаммов как отдельного вида биологической угрозы в рутинной деятельности создаваемого центра мониторинга.

\section{Синтетическая биология и биотерроризм}

Несмотря на то, что Женевский протокол, ратисицированный еще в 1925 г., и в настоящее время подписанный 65 государствами, запрещает разработку, производство и использование в военных действиях биологического и химического оружия, преднамеренное использование ПБА предполагалось только в качестве компонентов биологического оружия при ведении военных действий [68]. Впервые Всемирная организация здравоохранения (ВО3) идентифицировала применение биологического и химического оружия в разгар войны во Вьетнаме, что привело к принятию резолюции ООН 2162В (XXI) от 1967 г., осуждающей все подобные действия, противоречащие Женевскому протоколу. В 1970 г. в ВОЗ был подготовлен доклад «Медико-санитарные аспекты применения химического и биологического оружия», обновленный в 2004 г. руководством «Ответные меры системы общественного здоровья при применении биологического и химического оружия» [69]. Этот документ включает рекомендации по выявлению вспышек новых необычных болезней и реагированию на них. Руководство описывает также стандартизированные рекомендации по наблюдению и предоставлению адекватной медицинской помощи в случаях таких чрезвычайных ситуаций. По определению ВОЗ к биологическому относится оружие, достигающее намеченной цели посредством инсиццирования болезнетворными микроорганизмами и другие подобными агентами, в том числе вирусами, инфекционными нуклеиновыми кислотами и прионами.

В настоящее время производство биологического оружия технологически легко доступно и открытая разработка не ведется только лишь вследствие опасений в отношении негативного международного общественного мнения или возмездия. Тем не менее многие страны обладают целым рядом возможностей использования биологического оружия. С 1928 г. некоторые страны имели наступательные программы биологической войны, и, скорее всего, до сих пор имеют возможность их реализовать [70]. США (до 1972 г.) и бывший Советский Союз (до 1992 г.) имели большие и тщательно проработанные доктрины ведения биологической войны. Обе страны разработали более десятка биологических агентов, в том числе токсинов, нацеленных на то, чтобы убить или вывести из строя людей и уничтожить растениеводство и животноводство на территориях потенциального противника [71, 72]. Вместе с тем использование биологических агентов в ходе военных действий запрещено Конвенцией о применении биологического и токсичного оружия (КБТО). С 1972 г. странам, подписавшим конвенцию, не разрешено проводить исследования с целью разработки биологического оружия, а также производить и накапливать БО. КБТО была подписана и ратифицирована в 170 странах. Однако отсутствуют какие-либо реальные механизмы проверки выполнения Конвенции. И разработку биологического оружия, и его производство довольно легко «спрятать» в биотехнологической инфраструктуре 
страны. Кроме того, Конвенция о биологическом оружии требует от стран, подписавших ее, «не разрабатывать, не производить, не накапливать или иным образом приобретать или сохранять микробиологические или другие биологические агенты или токсины, независимо от их происхождения или метода производства, в таких количествах, которые не имеют никакого оправдания для профилактических, защитных или других мирных целей». Таким образом, Конвенция не определяет точно, какие именно биологические агенты или токсины, запрещены, и какие их количества будут выходить за рамки, установленные Конвенцией. Однако страна (независимо от того, подписала она КБТО или нет), рискнувшая открыто разрабатывать или производить биологическое оружие имеет высокий шанс стать международным изгоем.

Биологический терроризм, осуществляемый в мирное время в различных целях, первоначально приравнивался к локальным угрозам в масштабе страны. Вероятность масштабирования последствий биотеррористического акта до уровня национальной безопасности носила гипотетический характер. Однако угроза биотерроризма стала реальностью после того, как в почтовой системе США были скрытно распространены письма с возбудителями сибирской язвы. В результате этой акции умерли пять человек, включая троих, непосредственно контактировавших с зараженной почтой, более 20 были инфицированы и несколько тысяч человек вынуждены принимать сильные антибиотики. Письма, содержащие споры возбудителя сибирской язвы или их имитаторы, обнаружены в десятках других стран, включая Россию.

Биотерроризм определяется как преднамеренное распространение вирусов, бактерий или других агентов с целью вызвать болезнь или смерть людей, а также гибель животных или растений [73]. Целями биотерроризма, как правило, являются желание вызвать страх, панику, социальные волнения или экономические потери; в основе актов могут лежать идеологические, религиозные или политические убеждения. Террористы стремятся достичь своей цели с помощью ужаса, вызванного насилием. Кроме того, существует апокалиптические секты, такие как Аум Синрике, стремящиеся вызвать массовые жертвы для достижения своих собственных религиозных целей. Однако террористы обычно действуют внутри определенных государств, структуры безопасности которых стремятся обнаружить и обезвредить их. Необходимость работать «под носом» у правоохранительных органов и относительно ограниченные финансовые и инфраструктурные возможности, с одной стороны, серьезно затрудняют возможности террористов в разработке и осуществлении успешной биологической атаки значимого масштаба. С другой стороны, успех для большинства из них, скорее всего, будет определен масштабом возникшей общественной истерии, и необязательно должен сопровождаться огромным количеством жертв [74-76].

Наконец, необходимо упомянуть и о биопреступлениях. Биопреступление подразумевает использование биологического агента с целью убийства одного человека или небольшой группы лиц, мотивированное местью или денежной выгодой, в большей степени, чем политическими, идеологическими, религиозными или другими убеждениями. Среди примеров биопреступлений можно назвать использование рицина с целью избавления от нежелательного партнера или инфицирование микроорганизмом Shigella dysenteriae, произведенное сотрудницей лаборатории больницы [77]. Убийство болгарского диссидента Георгия Маркова в Лондоне в 1978 г. с использованием рицин-содержащих гранул, введенных с помощью укола зонтиком, также можно считать актом биопреступления.

Масштабы финансовых последствий биотерроризма против человека и сельского хозяйства могут быть просто катастрофическими [75, 78-81].

До настоящего времени биотерроризм унес существенно меньше человеческих жизней, по сравнению с более традиционными формами терроризма с использованием оружия и взрывчатых веществ. Однако риск того что использование в качестве БО инфекционных агентов может привести к значительным жертвам, реален, хотя и не слишком велик. Например, длительность инкубационного периода, как правило, позволяет диагностировать патоген до пика симптоматических проявлений для многих биологических агентов, используемых в качестве БО. Кроме того, за исключением мультирезистентных супербактерий, эффективное лечение антибиотиками доступно для большинства, по крайней мере бактериальных, агентов.

Описано два принципиальных подхода к конструированию боевых ПБА:

а) перенос ранее существовавшего патогена от одного хозяина на другого, сопровождающийся тяжелым течением заболевания вследствие отсутствия адаптации у организма нового хозяина к воздействию патогена;

б) появление новых патогенных свойств у уже известного биологического агента, обычно реализуемых в ходе горизонтального переноса генов.

Использование первого подхода для создания новых биологических угроз до недавнего времени выглядело маловероятным, однако появление синтетической биологии сильно изменило шансы. Детальные механизмы, позволяющие предсказать какие конкретно мутации в геноме патогена приведут к возникновению возможности переноса его на нового хозяина, являются предметом активного изучения вирусологов и микробиологов, что делает перспективу создания БО на этой основе технически реализуемой [82-85].

Успехи современной синтетической биологии дают основания полагать, что в ближайшее время можно ожидать появления доступных методов синтеза новых организмов с заданными (программируемыми) свойствами для различных фундаментальных и прикладных целей. Ключевые открытия были сделаны коллективами Крейга Вентера и Дэниела Гиббсона. Они первыми показали возможность получения новых синтетических видов микроорганизмов с дизайнерским геномом [82-85].

Современный потенциал синтетической биологии сводится к нескольким ключевым функциям:

1) комбинированный химико-энзиматический синтез длинных фрагментов искусственно синтезированных фрагментов ДНК;

2) компьютерный дизайн отдельных генов и целых геномов с заданными метаболическими функциями;

3) высокоэффективная сборка и коррекция искусственно синтезированных геномов в простых биологических системах (клетки бактерий и одноклеточных эукариот);

4) полностью автоматизированный удаленный синтез ДНК, РНК, белков (токсинов), вирусов и бактерий без участия человека роботизированными комплексами из простых химических соединений. 
Перечисленные возможности позволяют в ближайшее время с помощью синтетической биологии:

1) проводить экспресс-разработку вакцин и вакцинных штаммов вирусов и бактерий любой природы, включая новые и неизвестные, без использования патогена в качестве исходного материала. Все что нужно - это знать последовательность генома патогена, который может быть отправлен в лабораторию или на автономный комплекс в виде электронного сообщения. Экспериментально продемонстрировано, что вакцина против гриппа может быть создана за 2 месяца если в качестве исходного материала была только информация о последовательности нового штамма гриппа A;

2) проводить удаленный синтез клеток бактерий для колонизации других планет в космических программах;

3) создавать животных - идеальных доноров органов для человека. После перенесения в их геном локусов генов, отвечающих за гистосовместимость;

4) проводить разработку и синтез вирусов и бактерий с заданными свойствами в террористических и военных целях

Еще более простым, в том числе с использованием методов синтетической биологии и редактирования генома, выглядит внедрение новых патогенных свойств уже в известные биологические агенты, для многих из которых давно известны и детально описаны механизмы их патогенеза. Кроме того, и для бактерий, и для вирусов имеется множество удобных и доступных биотехнологических систем горизонтального переноса, позволяющих достаточно быстро получить микроорганизм с заданными свойствами. В настоящее время потенциальному разработчику биологического оружия нет необходимости иметь природный образец, несущий в себе нужные ему гены вирулентности. На основании открытых баз данных, воспользовавшись услугами биотехнологических фирм, разработчик может синтезировать нужный ему ген de novo.

Итак, в качестве создания новых патогенных организмов с помощью генно-инженерных методов наиболее простым путем является модификация уже известных организмов путем внедрения в них генов вирулентности. Наиболее привлекательными вариантами для модификации представляются: 1) внедрение в целевые биологические агенты бактериальных токсинов; 2) добавление генов устойчивости к антибиотикам; 3) повышение чувствительности иммунной системы хозяина к патогену (цитокиновый шторм); 4) синтез генов вирулентности и даже отдельных небольших патогенных организмов de novo.

Другой возможностью для биотерроризма является вероятность получения ими доступа к биологическим агентам, разработанным в результате военных программ государства, и коллекциям патогенных микроорганизмов. Гражданская война, восстание и беззаконие в странах, обладающих такими программами, сопровождаются значительным риском распространения БО в такой ситуации. В то же время технологические инновации и быстрое развитие наук о жизни значительно улучшили наше понимание процессов взаимодействия возбудителей с хозяином и стимулировали развитие медицинских контрмер. Кроме того, они значительно увеличили наши возможности по выявлению и идентисикации патогенов. Одновременно технологические достижения, такие как сетевые видеокамеры и программное обеспечение, предназначенные для выявления важной разведывательной информации, стали мощными инструментами для борьбы с терроризмом и увеличили эффективность антитеррористических контрмер, предотвращающих нападение. Достижения в криминалистике привели к возможности эффективно расследовать инцидент и отследить происхождение примененного биологического агента. Тем не менее опасность появления новых ПБА, в том числе несущих признаки генно-инженерной модификации, чрезвычайно высока, а их появление каждый раз представляет собой серьезный вызов для мирового сообщества.

\section{ЗАКЛЮЧЕНИЕ}

Анализируя известные литературные данные о появлении новых патогенов в том числе с участием человека, можно заключить, что снижение угрозы появления новых патогенов и патогенов с новыми биологическими свойствами возможно лишь при условии активного внедрения в практику новых средств экспресс-диагностики инфекций в ЛПУ и окружающей среде. Однако ПБА, модифицированные человеком, все же имеют признаки других, ранее описанных, организмов, что делает задачу их индикации технологически возможной. Однако особый вид угрозы представляют ранее не изученные ПБА, по какимлибо причинам спонтанно приобретающие опасные для человечества свойства. Поэтому методы их идентификации также должны быть внедрены в перспективную сеть мониторинга биологических угроз.

Обеспечение биобезопасности является важной государственной задачей. Сохранение существующего уровня негативного воздействия опасных биологических факторов, возникновение новых и возвращение отдельных ранее преодоленных рисков, угрожает санитарноэпидемиологическому, ветеринарному, фитосанитарному и экологическому благополучию общества и ослабляет национальную безопасность в целом. В связи с этим требуется усиление готовности государства к предотвращению биогенных угроз различного происхождения.

В результате проведенного анализа литературных данных становится очевидно, что снижение угрозы появления НОВых ПБА (И ПБА с новыми биологическими свойствами) возможно лишь при условии активного внедрения новых средств экспресс-диагностики инфекций как в клинической практике, так и для поиска опасных ПБА в окружающей среде. Особое внимание необходимо уделить внедрению методов, направленных на поиск ранее не известных организмов, а также разработке профилактических и лечебных средств против вновь идентисиццируемых патогенов.

Целью настоящего обзора являлся комплексный анализ угроз национальной безопасности через поиск уязвимостей, свойственных существующему уровню контроля за инфекционными процессами. Во-первых, эти угрозы кроются в биологических особенностях эволюции самих ПБА, которые приводят к появлению новых патогенов или их новых свойств, включая уход от вакцинации и появление антибиотикорезистентности. Вовторых, угрозой является отсутствие или недостаточное внедрение технологий глубокого анализа и оперативного мониторинга, которым, в частности, посвящен ряд статей из настоящего номера журнала. В-третьих, уязвима сама система мониторинга биологических угроз в ее текущем состоянии вследствие межведомственной разрозненности и малой оперативности. В этой связи можно сделать вывод о необходимости скорейшего создания единого Национального интеграционного 
центра мониторинга биологических угроз, собирающего и обрабатывающего информацию обо всех биологических рисках из различных источников в режиме, приближенном к режиму реального времени, обеспечивающего хранение и анализ информации, моделирование развития ситуации, прогноз, ситуационное осведомление всех ответственных должностных лиц и выработку оптимального принятия управленческих решений на межведомственном уровне.

\section{Литература}

1. О биологической безопасности. Проект Федерального закона Российской Федерации. (ред. от августа 2016 г.). 30 с. Доступно по ссылке: http://regulation.gov.ru/projects\# npa $=55658$

2. Онищенко Г. Г., Попова А. Ю., Топорков В. П., Смоленский В. Ю., Щербакова С. А., Кутырев В. В. Современные угрозы и вызовы в области биологической безопасности и стратегия противодействия. Проблемы особо опасных инфекций. 2015; (3): 5-9.

3. О состоянии санитарно-эпидемиологического благополучия населения в Российской Федерации в 2017 году: Государственный доклад. М.: Федеральная служба по надзору в сфере защиты прав потребителей и благополучия человека; 2018. 268 с.

4. Покровский В .И., Брико Н. И. Эпидемиология. Учебник. М.: ГЭОТАР-Медиа; 2016. 368 с.

5. Лобзин Ю. В., Белозеров Е. С., Беляева Т. В, Волжанин В. М. Вирусные болезни человека. СПб.: СпецЛит; 2015. $400 \mathrm{c}$.

6. BioWatch and public health surveillance: Evaluating systems for the early detection of biological threats. Abbreviated version. Washington, DC: The National Academies Press. IOM and NRC. 2011. 252 p.

7. Онищенко Г. Г., Меркулов И. В., Петров Е. Ю., Желобов В. Е., Шевчук Н. А., Селедцова О. В. О ходе иммунизации населения В рамках национального календаря профилактических прививок. Протокол селекторного совещания у руководителя Федеральной службы по надзору в сфере защиты прав потребителей и благополучия человека (Протокол №13 от 20.07.2010). Доступно по ссылке: http://41.rospotrebnadzor.ru/content/protokol-protokolselektornogo-soveshchaniya-u-rukovoditelya-federalnoysluzhby-po-nadzoru-5

8. Основы государственной политики в области обеспечения химической и биологической безопасности Российской Федерации на период до 2025 года и дальнейшую перспективу (утв. Президентом РФ 1 ноября 2013 г. N Пр2573). Доступно по ссылке: http://www.garant.ru/products/ ipo/prime/doc/70423098/

9. Указ Президента РФ от 31.12.2015 N 683 «О Стратегии национальной безопасности Российской Федерации". Доступно по ссылке: http://www.consultant.ru/document/ cons_doc_LAW_191669/

10. В России создадут Центр по борьбе с биологическими угрозами. [Электронный ресурс] Paper 16 матра 2015. Available at: https://iz.ru/news/584008 (last accessed 12 September 2018)

11. Постановление Правительства РФ от 30 июня 2004 г. N 322 «Об утверждении Положения о Федеральной службе по надзору в сфере защиты прав потребителей и благополучия человека» (в ред. от 24 января 2017 г.). Доступно по ссылке: http://base.garant.ru/12136005/

12. Приказ Федеральной службы государственной статистики от 28 января 2014 г. N 52 «Об утверждении статистического инструментария для организации Федеральной службой по надзору в сфере защиты прав потребителей и благополучия человека федерального статистического наблюдения за заболеваемостью населения инфекционными и паразитарными болезнями и профилактическими прививками». Доступно по ссылке: http://www.garant.ru/products/ipo/prime/doc/70479106/
13. Статистический учет и отчетность учреждений здравоохранения. М.: Министерство здравоохранения и социального развития Российской Федерации. 2006. 81 с.

14. Федеральный закон от 30.03.1999 N 52-ФЗ «О санитарноэпидемиологическом благополучии населения» (в ред. от 03.07.2016). Доступно по ссылке: http://www.consultant.ru/ document/cons_doc_LAW_22481/

15. Постановление Правительства РФ от 2 февраля 2006 г. N 60 «Об утверждении Положения о проведении социальногигиенического мониторинга» (в ред. от 4 сентября 2012 г.). Доступно по ссылке: http://base.garant.ru/12144791/

16. СанПиН 2.3.2.1078-01. Гигиенические требования безопасности и пищевой ценности пищевых продуктов. Утверждены главным государственным санитарным врачом Российской Федерации 06 ноября 2001 г. Доступно по ссылке: http://base.garant.ru/4178234/

17. СанПиН 2.1.4.1074-01: Питьевая вода. Гигиенические требования к качеству воды централизованных систем питьевого водоснабжения. Контроль качества. Гигиенические требования к обеспечению безопасности систем горячего водоснабжения. Утверждены главным государственным санитарным врачом Российской Федерации 29 сентября 2001 г. Доступно по ссылке: http:// docs.cntd.ru/document/901798042

18. Перечень стандартов, содержащих правила и методь испытаний и измерений, в том числе правила отбора образцов, необходимые для применения и исполнения требований технического регламента Таможенного союза «Требования безопасности пищевых добавок, ароматизаторов и технологических вспомогательных средств» и осуществления оценки (подтверждения) соответствия. Приложение к Единым санитарноэпидемиологическим и гигиеническим требованиям к товарам, подлежащим санитарно-эпидемиологическому надзору (контролю). Утверждены Решением Комиссии Таможенного союза от 28 мая 2010 года № 299. (в ред. от 09 декабря 2011 г.)

19. Dzenitis JM, Makarewicz AJ. The Autonomous Pathogen Detection System. The Microflow Cytometer. 2010: 263-84.

20. Hindson BJ, Makarewicz AJ, Setlur US, Henderer BD, McBride MT, Dzenitis JM. APDS: the autonomous pathogen detection system. Biosens Bioelectron. 2005; 20 (10): 1925-31.

21. Онищенко Г. Г., Кузькин Б. П., Демина Ю. В. и др. Обеспечение готовности и организация работы СПЭБ ФКУЗ «Ставропольский противочумный институт" Роспотребнадзора в период проведения XXII Олимпийских и XI Паралимпийских зимних игр в Сочи. Проблемы особо опасных инфекций. 2015; (1): 58-62.

22. GAO-14-267T BIOSURVEILLANCE: Observations on the Cancellation of BioWatch Gen-3 and Future Considerations for the Program. GAO. Statement of Chris Currie, Acting Director, Homeland Security and Justice. Washington, D.C.: 2014.

23. Fournier PE, Raoult D. Prospects for the future using genomics and proteomics in clinical microbiology. Annu Rev Microbiol. 2011; (65): 169-188.

24. Diene SM, Bertelli C, Pillonel T, Schrenzel J, Greub G. Bacterial genomics and metagenomics: clinical applications and medical relevance. Rev Med Suisse. 2014; 10 (450): 2155-61.

25. Zhou K, Ferdous M, de Boer RF, Kooistra-Smid AM, Grundmann $\mathrm{H}$, Friedrich $\mathrm{AW}$, et al. The mosaic genome structure and phylogeny ofShiga toxin-producing Escherichia coli O104:H4 
is driven by short-termadaptation. Clin Microbiol Infect. 2015; 21 (468): e467-18.

26. Zhou K, Lokate M, Deurenberg RH, Tepper M, Arends JP, Raangs $E G$, et al. Use ofwhole-genome sequencing to trace, control and characterize the regionalexpansion of extended-spectrum beta-lactamase producing ST15 Klebsiellapneumoniae. Sci Rep. 2016; (6): 20840.

27. Weterings V, Zhou K, Rossen JW, van Stenis D, Thewessen E, Kluytmans $\mathrm{J}$, et al. An outbreak of colistin-resistant Klebsiella pneumoniaecarbapenemase-producing Klebsiella pneumoniae in the Netherlands (July-December 2013), with interinstitutional spread. Eur J Clin Microbiol Infect Dis. 2015; (34): 1647-55.

28. Ferdous M, Zhou K, de Boer RF, Friedrich AW, KooistraSmid AM, Rossen JW, Comprehensive characterization of Escherichia coli O104:H4isolated from patients in the Netherlands. Front Microbiol. 2015; (6): 1348

29. Bathoorn E, Rossen JW, Lokate M, Friedrich AW, Hammerum AM. Isolation of an NDM-5-producing ST16 Klebsiella pneumoniae from a Dutchpatient without travel history abroad, August 2015. Euro Surveil. 2015; (20): 30040

30. Falgenhauer L, Waezsada SE, Yao Y, Imirzalioglu C, Kasbohrer A, Chakraborty T. Colistin resistance gene mcr-1 in extendedspectrumbeta-lactamase-producing and carbapenemaseproducing Gram-negativebacteria in Germany. Lancet Infect Dis. 2016; (16): 282-283.

31. Aanensen DM, Feil EJ, Holden MT, Dordel J, Yeats CA Fedosejev $A$, et al. Whole-genome sequencing for routine pathogen surveillancein public health: a population snapshot of invasive Staphylococcus aureus in Europe. Mbio. 2016; 7 (3): e00444-16.

32. Fournier PE, Dubourg G, Raoult D. Clinical detection and characterizationof bacterial pathogens in the genomics era. Genome Med. 2014; (6): 114

33. Hasman H, Saputra D, Sicheritz-Ponten T, Lund O, Svendsen CA Frimodt-Moller N, et al. Rapid whole-genome sequencing fordetection and characterization of microorganisms directly from clinicalsamples. J Clin Microbiol. 2014; (52): 139-46.

34. Franz E, Delaquis P, Morabito S, Beutin L, Gobius K, Rasko DA, et al. Exploiting the explosion ofinformation associated with whole genome sequencing to tackle Shigatoxin-producing Escherichia coli (STEC) in global food production systems. Int J Food Microbiol. 2014; (187): 57-72.

35. Laabei M, Recker M, Rudkin JK, Aldeljawi M, Gulay Z, Sloan TJ, et al Predicting the virulence of MRSA from its genome sequence. Genome Res. 2014; (24): 839-49.

36. Ferdous M, Friedrich AW, Grundmann H, de Boer RF, Croughs PD, Islam MA, et al. Molecular characterization and phylogeny of Shiga toxin-producingEscherichia coli isolates obtained from two Dutch regions using whole genomesequencing. Clin Microbiol Infect 2016; (22): 642.e1-642.e9.

37. Nijhuis RH, Oueslati S, Zhou K, Bosboom RW, Rossen JW Naas T, et al. OXY-2-15, a novel variant showing increased ceftazidime hydrolytic activity. J Antimicrob Chemother. 2015; (70): 1429-33

38. Hasman H, Saputra D, Sicheritz-Ponten T, Lund O, Svendsen CA Frimodt-Moller N, et al. Rapid whole-genome sequencing fordetection and characterization of microorganisms directly from clinicalsamples. J Clin Microbiol 2014; (52): 139-46.

39. Patel JB. 16S rRNA gene sequencing for bacterial pathogen identification inthe clinical laboratory. Mol Diagn. 2001; (6): 313-21.

40. Schuurman T, de Boer RF, Kooistra-Smid AM, van Zwet AA Prospectivestudy of use of PCR amplification and sequencing of $16 \mathrm{~S}$ ribosomal DNA fromcerebrospinal fluid for diagnosis of bacterial meningitis in a clinical setting. J Clin Microbiol. 2004; (42): 734-40.

41. Srinivasan L, Pisapia JM, Shah SS, Halpern CH, Harris MC. Canbroad-range $16 \mathrm{~S}$ ribosomal ribonucleic acid gene polymerase chain reactionsimprove the diagnosis of bacterial meningitis? A systematic review andmeta-analysis. Ann Emerg Med. 2012; (60): 609-20.

42. Kalia VC, Kumar R, Kumar P, Koul S. A genome-wide profiling strategy asan aid for searching unique identification biomarkers for Streptococcus. Indian J Microbiol. 2016; (56): 46-58.

43. Sabat AJ, van Zanten E, Akkerboom V, Wisselink G, van Slochteren K, de Boer RF. Targetedamplification for bacterial identification at the species-level usingnextgeneration sequencing-increased discrimination of closely relatedspecies. ECCMID. 2016; E-poster EP0219.

44. Daubin V, Gouy M, Perriere G. Bacterial molecular phylogeny usingsupertree approach. Genome Inform. 2001; (12): 155-64.

45. Thompson CC, Chimetto L, Edwards RA, Swings J, Stackebrandt E, Thompson FL. Microbial genomic taxonomy. BMC Genom. 2013; (14): 913.

46. Tenover FC, Arbeit RD, Goering RV. How to select and interpretmolecular strain typing methods for epidemiological studies of bacterialinfections: a review for healthcare epidemiologists. Molecular Typing WorkingGroup of the Society for Healthcare Epidemiology of America. Infect Control Hosp Epidemiol. 1997; (18): 426-39.

47. Sabat AJ, Budimir A, Nashev D, Sa-Leao R, van Dijl J, Laurent $F$, et al. Overview of molecular typing methods for outbreakdetection and epidemiological surveillance. Euro Surveil. 2013; (18): 20380.

48. Harrison EM, Paterson GK, Holden MT, Larsen J, Stegger M, Larsen AR, et al. Whole genomesequencing identifies zoonotic transmission of MRSA isolates with the novelmecA homologue mecC. EMBO Mol Med. 2013; (5): 509-15.

49. Макаров В. В., Хромов А. В., Гущин В. А., Ткачук А. П. Возникновение новых инфекций в 21 веке и способы их идентификации с использованием высокопроизводительного секвенирования (NGS). Вестник РГМУ. 2017; (1): 5-25.

50. Яковлев С. В., Суворова М. П. , Белобородов В. Б., Басин Е. Е., Елисеева Е. В., Ковеленов С. В. и др. Распространенность и клиническое значение нозокомиальных инфекций в лечебных учреждениях России: исследование ЭРГИНИ. Антибиотики и химиотерапия 2016; 61 (5-6): 32-42.

51. Козлов Р. С. Пневмококки: уроки прошлого - взгляд в будущее. Смоленск: МАКМАХ; 2010.

52. Paterson DL, Rossi F, Baquero F, et al. In vitro susceptibilities of aerobic and facultative Gram-negative bacilli isolated from patient with intra-abdominal infections worldwide: the 2003 Study for Monitoring Antimicrobial Resistance Trend (SMART). J Antimicrob Chemother. 2005; (55): 965-73.

53. Научный отчет о результатах исследования антибиотикорезистентности бактериальных возбудителей нозокомиальных инфекций в отделениях с интенсивным использованием антибиотиков в стационарах России (РеВАНШ). Смоленск: Научно-исследовательский институт антимикробной химиотерапии; 2009

54. Bonomo RA, Burd EM, Conly J, Limbago BM, Poirel L, Segre JA, Westblade LF. Carbapenemase-Producing Organisms: A Global Scourge. Clin Infect Dis. 2017 Oct 16.

55. Kohler PP, Volling C, Green K, Uleryk EM, Shah PS, McGeer A. Carbapenem Resistance, Initial Antibiotic Therapy, and Mortality in Klebsiella pneumoniae Bacteremia: A Systematic Review and Meta-Analysis. Infect Control Hosp Epidemiol. 2017 Nov; 38 (11): 1319-28.

56. Zavascki AP, Barth AL, Gaspareto PB, et al. Risk factors for nosocomial infections due to Pseudomonas aeruginosa producing metallo-beta-lactamase in two tertiary-care teaching hospitals. J Antimicrob Chemother. 2006; (58): 882-5.

57. Messadi AA, Lamia T, Kamel B, et al. Association between antibiotic use and changes in susceptibility patterns of $P$. aeruginosa in an intensive care unit: a 5-year study, 20002004. Burns. 2008; (34):1098-102.

58. Яковлев С. В., Проценко Д. Н., Шахова Т. В. и др. Антибиотикорезистентность в стационаре: контролируем ли мы ситуацию? Антибиотики и химиотерапия. 2010; 55 (1-2): 50-58

59. Tacconelli E, De Angelis G, Cataldo MA, et al. Does antibiotic exposure increase the risk of methicillinresistant Staphylococcus aureus (MRSA) isolation? A systematic review and meta-analysis. J Antimicrob Chemother. 2008; (61): 
26-38.

60. Sarma JB, Ahmed GU. Characterisation of methicillin resistant S. aureus strains and risk factors for acquisition in a teaching hospital in northeast India. Indian J Med Microbiol. 2010; (28): 127-9.

61. Fair RJ, Tor Y. Antibiotics and bacterial resistance in the 21st century. Perspect Med Chem. 2014; (6): 25-64.

62. Curcio D. Multidrug-resistant Gram-negative bacterial infections: are you ready for the challenge? Curr Clin Pharmacol. 2014; (9): 27-38.

63. De Angelis GD, D'Inzeo T, Fiori B, et al. Burden of antibiotic resistant Gram-negative bacterial infections: evidence and limits. J Med Microbiol Diagn. 2014; (3): 132-37.

64. Глобальный план действий по борьбе с устойчивостью к противомикробным препаратам. ВОЗ. 2016 г. 7 с. Доступно по ссылке: http://apps.who.int/gb/ebwha/pdf_files/WHA69/ A69_24-ru.pdf

65. Яковлев С. В., Проценко Д. Н., Шахова Т. В. и др. Антибиотикорезистентность в стационаре: контролируем ли мы ситуацию? Антибиотики и химиотерапия. 2010; 55 (1-2): 50-8.

66. Яковлев С. В., Сидоренко С. В., Рафальский В. В., Спичак Т. В., редакторы. Стратегия и тактика рационального применения антимикробных средств в амбулаторной практике. Российские практические рекомендации. М.: Издательство «Пре100принт»; 2014. 121 с.

67. Blair JM, Webber MA, Baylay AJ, et al. Molecular mechanisms of antibiotic resistance. Nat Rev Microbiol. 2015; (13): 42-51.

68. The Protocol for the Prohibition of the Use in War of Asphyxiating, Poisonous or Other Gases, and of Bacteriological Methods of Warfare. United Nations (1925). Available from: http://www. un.org/disarmament/WMD/Bio/1925GenevaProtocol.shtml (last accessed 12 December 2015).

69. World Health Organization. Public health response to biological and chemical weapons - WHO guidance, 2nd edn. Geneva: WHO, 2004

70. Nuclear Threat Initiative. Available from: http://www.nti.org/ country-profiles (last accessed 12 December 2015).

71. Atlas RM. The medical threat of biological weapons. Crit Rev Microbiol. 1998; (24): 157-68.

72. Leitenberg M, Zilinskas RA, editors. The Soviet biological weapons program: a history. Cambridge, MA: Harvard University Press; 2012.

73. Centers for Disease Control and Prevention. Webpage Emergency Preparedness and Response. Specific hazards:
Bioterrorism. Available from: http://www.bt.cdc.gov/ bioterrorism (last accessed 12 December 2015).

74. Carus WS. Bioterrorism and biocrimes: the illicit use of biological agents since 1900. February 2001 revision. Washington, DC: Center for Counterproliferation Research, National Defense University. 2001. Available from: http://www.fas.org/irp/ threat/cbw/carus.pdf (last accessed 12 December 2015).

75. Ackermann GA, Moran KS. Bioterrorism and threat assessment. Weapons of Mass Destruction Commission. 2004. Available from: www.blixassociates.com/wp-content/ uploads/2011/03/No22.pdf (last accessed 12 December 2015).

76. Dando M. Bioterrorism: what is the real threat? Science and Technology Report No. 3. UK Global Health Policy Programme. London: The Nuffield Trust, 2005.

77. Kolavic SA, Kimura A, Simons SL, et al. An outbreak of Shigella dysenteriae Type 2 among laboratory workers due to intentional food contamination. JAMA. 1997; (278): 396-8.

78. Wheelis M, Casagrande R, Madden LV. Biological attack on agriculture: low-tech, high-impact bioterrorism. Bioscience. 2002; (52): 569-76.

79. Bourn J. The 2001 Outbreak of Foot and Mouth Disease. Report by the Comptroller and Auditor General, HC 939 Session 2001-2002. London, UK, National Audit Office. 2002. Available from: www.nao.gov.uk (last accessed 12 December 2015).

80. Meuwissen MPM, Van Boven M, Hagenaars TJ, et al. Predicting future costs of high-pathogenicity avian influenza epidemics: large versus small uncertainties. NJAS. 2006; (52): 195-205.

81. Schmitt K, Zacchia NA. Total decontamination cost of the anthrax letter attacks. Biosecur Bioterror. 2012; (10): 1-10.

82. Gibson DG1, Glass JI, Lartigue C, Noskov VN, Chuang RY, Algire MA, et al. Creation of a bacterial cell controlled by a chemically synthesized genome. Science. 2010 Jul 2; 329 (5987): 52-6. DOI: 10.1126/science.1190719.

83. Gibson DG, Venter JC. Synthetic biology: Construction of a yeast chromosome. Nature. 2014 May 8; 509 (7499): 168-9. DOI: 10.1038/509168a

84. Hutchison CA, Chuang RY, Noskov VN, Assad-Garcia N Deerinck TJ, Ellisman $\mathrm{MH}$, et al. Design and synthesis of a minimal bacterial genome. Science. 2016 Mar 25; 351 (6280): aad6253. DOI: 10.1126/science.aad6253.

85. Boles KS, Kannan K, Gill J, Felderman M, Gouvis H, Hubby B, et al. Digital-to-biological converter for on-demand production of biologics. Nature Biotechnology. 2017; (35): 672-5.

\section{References}

1. O biologicheskoj bezopasnosti. Proekt Federal'nogo zakona Rossijskoj Federacii. (red. ot avgusta 2016 g.). 30 s. Dostupno po ssylke: http://regulation.gov.ru/projects\#npa $=55658$

2. Onishhenko GG, Popova AJu, Toporkov VP, Smolenskii VJu, Shherbakova SA, Kutyrev VV. Sovremennye ugrozy i vyzovy $\checkmark$ oblasti biologicheskoj bezopasnosti i strategija protivodejstvija. Problemy osobo opasnyh infekcij. 2015; (3): 5-9.

3. O sostojanii sanitarno-jepidemiologicheskogo blagopoluchija naselenija v Rossijskoj Federacii v 2017 godu: Gosudarstvennyj doklad. M.: Federal'naja sluzhba po nadzoru v sfere zashhity prav potrebitelej i blagopoluchija cheloveka; 2018. 268 s.

4. Pokrovskij VI, Briko NI. Jepidemiologija. Uchebnik. M.: GJeOTAR-Media; 2016. 368 s.

5. Lobzin JuV, Belozerov ES, Beljaeva TV, Volzhanin VM. Virusnye bolezni cheloveka. SPb.: SpecLit; 2015. 400 s.

6. BioWatch and public health surveillance: Evaluating systems for the early detection of biological threats. Abbreviated version. Washington, DC: The National Academies Press. IOM and NRC. 2011. $252 \mathrm{p}$

7. Onishhenko GG, Merkulov IV, Petrov EJu, Zhelobov VE, Shevchuk NA, Seledcova OV. O hode immunizacii naselenija

$\checkmark$ ramkah nacional'nogo kalendarja profilakticheskih privivok. Protokol selektornogo soveshhanija u rukovoditelja Federal'noj sluzhby po nadzoru $v$ sfere zashhity prav potrebitelej i blagopoluchija cheloveka (Protokol \#13 ot 20.07.2010). Dostupno po ssylke: http://41.rospotrebnadzor. ru/content/protokol-protokol-selektornogo-soveshchaniya-urukovoditelya-federalnoy-sluzhby-po-nadzoru-5

8. Osnovy gosudarstvennoj politiki $\vee$ oblasti obespechenija himicheskoj i biologicheskoj bezopasnosti Rossijskoj Federacii na period do 2025 goda i dal'nejshuju perspektivu (utv. Prezidentom RF 1 nojabrja 2013 g. N Pr-2573). Dostupno po ssylke: http://www.garant.ru/products/ipo/ prime/doc/70423098/

9. Ukaz Prezidenta RF ot 31.12.2015 N 683 "O Strategii nacional'noj bezopasnosti Rossijskoj Federacii». Dostupno po ssylke: http://www.consultant.ru/document/cons_doc_ LAW 191669/

10. V Rossii sozdadut Centr po bor'be s biologicheskimi ugrozami. [Jelektronnyj resurs] Paper 16 matra 2015. Dostupno po ssylke: https://iz.ru/news/584008 (last accessed 12 September 2018).

11. Postanovlenie Pravitel'stva RF ot 30 ijunja 2004 g. N 322 «Ob utverzhdenii Polozhenija o Federal'noj sluzhbe po nadzoru v 
sfere zashhity prav potrebitelej i blagopoluchija cheloveka» (v red. ot 24 janvarja 2017 g.). Dostupno po ssylke: http://base. garant.ru/12136005/

12. Prikaz Federal'noj sluzhby gosudarstvennoj statistiki ot 28 janvarja 2014 g. N 52 «Ob utverzhdenii statisticheskogo instrumentarija dlja organizacii Federal'noj sluzhboj po nadzoru $v$ sfere zashhity prav potrebitelej i blagopoluchija cheloveka federal'nogo statisticheskogo nabljudenija za zabolevaemost'ju naselenija infekcionnymi i parazitarnymi boleznjami i profilakticheskimi privivkami». Dostupno po ssylke: http://www.garant.ru/products/ipo/prime/doc/70479106/

13. Statisticheskij uchet i otchetnost' uchrezhdenij zdravoohranenija. M.: Ministerstvo zdravoohranenija social'nogo razvitija Rossijskoj Federacii. 2006. $81 \mathrm{~s}$.

14. Federal'nyj zakon ot 30.03.1999 N 52-FZ "O sanitarnojepidemiologicheskom blagopoluchii naselenija» ( $v$ red. ot 03.07.2016). Dostupno po ssylke: http://www.consultant.ru/ document/cons_doc_LAW_22481/

15. 15. Postanovlenie Pravitel'stva RF ot 2 fevralja $2006 \mathrm{~g}$. $\mathrm{N} 60$ «Ob utverzhdenii Polozhenija o provedenii social'nogigienicheskogo monitoringa» (v red. ot 4 sentjabrja 2012 g.). Dostupno po ssylke: http://base.garant.ru/12144791/

16. SanPiN 2.3.2.1078-01. Gigienicheskie trebovanija bezopasnosti i pishhevoj cennosti pishhevyh produktov. Utverzhdeny glavnym gosudarstvennym sanitarnym vrachom Rossijskoj Federacii 06 nojabrja 2001 g. Dostupno po ssylke: http://base.garant.ru/4178234/

17. SanPiN 2.1.4.1074-01: Pit'evaja voda. Gigienicheskie trebovanija k kachestvu vody centralizovannyh sistem pit'evogo vodosnabzhenija. Kontrol' kachestva. Gigienicheskie trebovanija k obespecheniju bezopasnosti sistem gorjachego vodosnabzhenija. Utverzhdeny glavnym gosudarstvennym sanitarnym vrachom Rossijskoj Federacii 29 sentjabrja $2001 \mathrm{~g}$ Dostupno po ssylke: http://docs.cntd.ru/document/901798042

18. Perechen' standartov, soderzhashhih pravila i metody ispytanij i izmerenij, v tom chisle pravila otbora obrazcov, neobhodimye dlja primenenija i ispolnenija trebovanij tehnicheskogo reglamenta Tamozhennogo sojuza «Trebovanija bezopasnost pishhevyh dobavok, aromatizatorov i tehnologicheskih vspomogatel'nyh sredstv» i osushhestvlenija ocenki (podtverzhdenija) sootvetstvija. Prilozhenie k Edinym sanitarnojepidemiologicheskim i gigienicheskim trebovanijam k tovaram, podlezhashhim sanitarno-jepidemiologicheskomu nadzoru (kontrolju). Utverzhdeny Resheniem Komissii Tamozhennogo sojuza ot 28 maja 2010 goda \# 299. (v red. ot 09 dekabrja 2011 g.)

19. Dzenitis JM, Makarewicz AJ. The Autonomous Pathogen Detection System. The Microflow Cytometer. 2010: 263-84.

20. Hindson BJ, Makarewicz AJ, Setlur US, Henderer BD, McBride MT, Dzenitis JM. APDS: the autonomous pathogen detection system. Biosens Bioelectron. 2005; 20 (10): 1925-31.

21. Onishhenko GG, Kuzkin BP, Demina JuV. i dr. Obespechenie gotovnosti i organizacija raboty SPJeB FKUZ «Stavropol'skij protivochumnyj institut» Rospotrebnadzora v period provedenija XXII Olimpijskih i XI Paralimpijskih zimnih igr v Sochi. Problemy osobo opasnyh infekcij. 2015; (1): 58-62.

22. GAO-14-267T BIOSURVEILLANCE: Observations on the Cancellation of BioWatch Gen-3 and Future Considerations for the Program. GAO. Statement of Chris Currie, Acting Director, Homeland Security and Justice. Washington, D.C.: 2014.

23. Fournier PE, Raoult D. Prospects for the future using genomics and proteomics in clinical microbiology. Annu Rev Microbiol. 2011; (65): 169-188.

24. Diene SM, Bertelli C, Pillonel T, Schrenzel J, Greub G. Bacterial genomics and metagenomics: clinical applications and medical relevance. Rev Med Suisse. 2014; 10 (450): 2155-61.

25. Zhou K, Ferdous M, de Boer RF, Kooistra-Smid AM, Grundmann H, Friedrich AW, et al. The mosaic genome structure and phylogeny ofShiga toxin-producing Escherichia coli 0104:H4 is driven by short-termadaptation. Clin Microbiol Infect. 2015; 21 (468): e467-18.

26. Zhou K, Lokate M, Deurenberg RH, Tepper M, Arends JP, Raangs $E G$, et al. Use ofwhole-genome sequencing to trace, control and characterize the regionalexpansion of extended-spectrum beta-lactamase producing ST15 Klebsiellapneumoniae. Sci Rep. 2016; (6): 20840.

27. Weterings V, Zhou K, Rossen JW, van Stenis D, Thewessen E, Kluytmans J, et al. An outbreak of colistin-resistant Klebsiella pneumoniaecarbapenemase-producing Klebsiella pneumoniae in the Netherlands (July-December 2013), with inter-institutional spread. Eur J Clin Microbiol Infect Dis. 2015. (34): 1647-55

28. Ferdous M, Zhou K, de Boer RF, Friedrich AW, KooistraSmid AM, Rossen JW, Comprehensive characterization of Escherichia coli 0104:H4isolated from patients in the Netherlands. Front Microbiol. 2015; (6): 1348.

29. Bathoorn E, Rossen JW, Lokate M, Friedrich AW, Hammerum AM. Isolation of an NDM-5-producing ST16 Klebsiella pneumoniae from a Dutchpatient without travel history abroad, August 2015. Euro Surveil. 2015; (20): 30040.

30. Falgenhauer L, Waezsada SE, Yao Y, Imirzalioglu C, Kasbohrer A, Chakraborty T. Colistin resistance gene mcr-1 in extendedspectrumbeta-lactamase-producing and carbapenemaseproducing Gram-negativebacteria in Germany. Lancet Infect Dis. 2016; (16): 282-283.

31. Aanensen DM, Feil EJ, Holden MT, Dordel J, Yeats CA, Fedosejev A, et al. Whole-genome sequencing for routine pathogen surveillancein public health: a population snapshot of invasive Staphylococcus aureus in Europe. Mbio. 2016; 7 (3): e00444-16.

32. Fournier PE, Dubourg G, Raoult D. Clinical detection and characterizationof bacterial pathogens in the genomics era. Genome Med. 2014; (6): 114

33. Hasman H, Saputra D, Sicheritz-Ponten T, Lund O, Svendsen CA, Frimodt-Moller $\mathrm{N}$, et al. Rapid whole-genome sequencing fordetection and characterization of microorganisms directly from clinicalsamples. J Clin Microbiol. 2014; (52): 139-46.

34. Franz E, Delaquis P, Morabito S, Beutin L, Gobius K, Rasko DA et al. Exploiting the explosion ofinformation associated with whole genome sequencing to tackle Shigatoxin-producing Escherichia coli (STEC) in global food production systems. Int J Food Microbiol. 2014; (187): 57-72.

35. Laabei M, Recker M, Rudkin JK, Aldeljawi M, Gulay Z, Sloan TJ, et al. Predicting the virulence of MRSA from its genome sequence. Genome Res. 2014; (24): 839-49.

36. Ferdous M, Friedrich AW, Grundmann H, de Boer RF, Croughs PD, Islam MA, et al. Molecular characterization and phylogeny of Shiga toxin-producingEscherichia coli isolates obtained from two Dutch regions using whole genomesequencing. Clin Microbiol Infect 2016; (22): 642.e1-642.e9.

37. Nijhuis RH, Oueslati S, Zhou K, Bosboom RW, Rossen JW, Naas $T$, et al. OXY-2-15, a novel variant showing increased ceftazidime hydrolytic activity. J Antimicrob Chemother. 2015; (70): 1429-33.

38. Hasman H, Saputra D, Sicheritz-Ponten T, Lund O, Svendsen CA, Frimodt-Moller N, et al. Rapid whole-genome sequencing fordetection and characterization of microorganisms directly from clinicalsamples. J Clin Microbiol 2014; (52): 139-46.

39. Patel JB. 16S rRNA gene sequencing for bacterial pathogen identification inthe clinical laboratory. Mol Diagn. 2001; (6): 313-21.

40. Schuurman T, de Boer RF, Kooistra-Smid AM, van Zwet AA. Prospectivestudy of use of PCR amplification and sequencing of $16 \mathrm{~S}$ ribosomal DNA fromcerebrospinal fluid for diagnosis of bacterial meningitis in a clinical setting. J Clin Microbiol. 2004; (42): 734-40.

41. Srinivasan L, Pisapia JM, Shah SS, Halpern CH, Harris MC. Canbroad-range $16 \mathrm{~S}$ ribosomal ribonucleic acid gene polymerase chain reactionsimprove the diagnosis of bacterial meningitis? A systematic review andmeta-analysis. Ann Emerg Med. 2012; (60): 609-20.

42. Kalia VC, Kumar R, Kumar P, Koul S. A genome-wide profiling strategy asan aid for searching unique identification biomarkers for Streptococcus. Indian J Microbiol. 2016; (56): 46-58.

43. Sabat AJ, van Zanten E, Akkerboom V, Wisselink G, van Slochteren K, de Boer RF. Targetedamplification for 
bacterial identification at the species-level usingnextgeneration sequencing-increased discrimination of closely relatedspecies. ECCMID. 2016; E-poster EP0219.

44. Daubin V, Gouy M, Perriere G. Bacterial molecular phylogeny usingsupertree approach. Genome Inform. 2001; (12): 155-64.

45. Thompson CC, Chimetto L, Edwards RA, Swings J, Stackebrandt E, Thompson FL. Microbial genomic taxonomy. BMC Genom. 2013; (14): 913.

46. Tenover FC, Arbeit RD, Goering RV. How to select and interpretmolecular strain typing methods for epidemiological studies of bacterialinfections: a review for healthcare epidemiologists. Molecular Typing WorkingGroup of the Society for Healthcare Epidemiology of America. Infect Control Hosp Epidemiol. 1997; (18): 426-39.

47. Sabat AJ, Budimir A, Nashev D, Sa-Leao R, van Dijl J, Laurent $F$, et al. Overview of molecular typing methods for outbreakdetection and epidemiological surveillance. Euro Surveil. 2013; (18): 20380.

48. Harrison EM, Paterson GK, Holden MT, Larsen J, Stegger M, Larsen AR, et al. Whole genomesequencing identifies zoonotic transmission of MRSA isolates with the novelmecA homologue mecC. EMBO Mol Med. 2013; (5): 509-15.

49. Makarov VV, Hromov AV, Gushhin VA, Tkachuk AP. Vozniknovenie novyh infekcij $\vee 21$ veke i sposoby in identifikacii $s$ ispol'zovaniem vysokoproizvoditel'nogo sekvenirovanija (NGS). Vestnik RGMU. 2017; (1): 5-25.

50. Jakovlev SV, Suvorova MP, Beloborodov VB, Basin EE, Eliseeva EV, Kovelenov SV. i dr. Rasprostranennost' i klinicheskoe znachenie nozokomial'nyh infekcij v lechebnyh uchrezhdenijah Rossii: issledovanie JeRGINI. Antibiotiki i himioterapija 2016; 61 (5-6): 32-42.

51. Kozlov RS. Pnevmokokki: uroki proshlogo - vzgljad v budushhee. Smolensk: MAKMAH; 2010.

52. Paterson DL, Rossi F, Baquero F, et al. In vitro susceptibilities of aerobic and facultative Gram-negative bacilli isolated from patient with intra-abdominal infections worldwide: the 2003 Study for Monitoring Antimicrobial Resistance Trend (SMART). J Antimicrob Chemother. 2005; (55): 965-73.

53. Nauchnyj otchet 0 rezul'tatah issledovanija antibiotikorezistentnosti bakterial'nyh vozbuditelej nozokomial'nyh infekcij $v$ otdelenijah $s$ intensivnym ispol'zovaniem antibiotikov $v$ stacionarah Rossii (ReVANSh). Smolensk: Nauchno-issledovatel'skij institut antimikrobnoj himioterapii; 2009.

54. Bonomo RA, Burd EM, Conly J, Limbago BM, Poirel L, Segre JA, Westblade LF. Carbapenemase-Producing Organisms: A Global Scourge. Clin Infect Dis. 2017 Oct 16.

55. Kohler PP, Volling C, Green K, Uleryk EM, Shah PS, McGeer A. Carbapenem Resistance, Initial Antibiotic Therapy, and Mortality in Klebsiella pneumoniae Bacteremia: A Systematic Review and Meta-Analysis. Infect Control Hosp Epidemiol. 2017 Nov; 38 (11): 1319-28.

56. Zavascki AP, Barth AL, Gaspareto PB, et al. Risk factors for nosocomial infections due to Pseudomonas aeruginosa producing metallo-beta-lactamase in two tertiary-care teaching hospitals. J Antimicrob Chemother. 2006; (58): 882-5.

57. Messadi AA, Lamia T, Kamel B, et al. Association between antibiotic use and changes in susceptibility patterns of $P$. aeruginosa in an intensive care unit: a 5-year study, 20002004. Burns. 2008; (34):1098-102

58. Jakovlev SV, Procenko DN, Shahova TV. i dr. Antibiotikorezistentnost' $v$ stacionare: kontroliruem li my situaciju? Antibiotiki i himioterapija. 2010; 55 (1-2): 50-58.

59. Tacconelli E, De Angelis G, Cataldo MA, et al. Does antibiotic exposure increase the risk of methicillinresistant Staphylococcus aureus (MRSA) isolation? A systematic review and meta-analysis. J Antimicrob Chemother. 2008; (61): 2638.

60. Sarma JB, Ahmed GU. Characterisation of methicillin resistant S. aureus strains and risk factors for acquisition in a teaching hospital in northeast India. Indian J Med Microbiol. 2010; (28): 127-9.

61. Fair RJ, Tor Y. Antibiotics and bacterial resistance in the 21st century. Perspect Med Chem. 2014; (6): 25-64.

62. Curcio D. Multidrug-resistant Gram-negative bacterial infections: are you ready for the challenge? Curr Clin Pharmacol. 2014; (9): 27-38.

63. De Angelis GD, D'Inzeo T, Fiori B, et al. Burden of antibiotic resistant Gram-negative bacterial infections: evidence and limits. J Med Microbiol Diagn. 2014; (3): 132-37.

64. Global'nyj plan dejstvij po bor'be s ustojchivost'ju k protivomikrobnym preparatam. VOZ. 2016 g. 7 s. Dostupno po ssylke: http://apps.who.int/gb/ebwha/pdf_files/WHA69/ A69_24-ru.pdf

65. Jakovlev SV, Procenko DN, Shahova TV. i dr. Antibiotikorezistentnost' $v$ stacionare: kontroliruem li my situaciju? Antibiotiki i himioterapija. 2010; 55 (1-2): 50-8.

66. Jakovlev SV, Sidorenko SV, Rafal'skij VV, Spichak TV, redaktory. Strategija i taktika racional'nogo primenenija antimikrobnyh sredstv $\mathrm{v}$ ambulatornoj praktike. Rossijskie prakticheskie rekomendacii. M.: Izdatel'stvo «Pre100print»; 2014. 121 s.

67. Blair JM, Webber MA, Baylay AJ, et al. Molecular mechanisms of antibiotic resistance. Nat Rev Microbiol. 2015; (13): 42-51.

68. The Protocol for the Prohibition of the Use in War of Asphyxiating, Poisonous or Other Gases, and of Bacteriological Methods of Warfare. United Nations (1925). Available from: http://www. un.org/disarmament/WMD/Bio/1925GenevaProtocol.shtml (last accessed 12 December 2015).

69. World Health Organization. Public health response to biological and chemical weapons - WHO guidance, 2nd edn. Geneva: WHO, 2004.

70. Nuclear Threat Initiative. Available from: http://www.nti.org/ country-profiles (last accessed 12 December 2015).

71. Atlas RM. The medical threat of biological weapons. Crit Rev Microbiol. 1998; (24): 157-68.

72. Leitenberg M, Zilinskas RA, editors. The Soviet biological weapons program: a history. Cambridge, MA: Harvard University Press; 2012.

73. Centers for Disease Control and Prevention. Webpage Emergency Preparedness and Response. Specific hazards: Bioterrorism. Available from: http://www.bt.cdc.gov/ bioterrorism (last accessed 12 December 2015).

74. Carus WS. Bioterrorism and biocrimes: the illicit use of biological agents since 1900. February 2001 revision. Washington, DC: Center for Counterproliferation Research, National Defense University. 2001. Available from: http://www.fas.org/irp/ threat/cbw/carus.pdf (last accessed 12 December 2015).

75. Ackermann GA, Moran KS. Bioterrorism and threat assessment. Weapons of Mass Destruction Commission. 2004. Available from: www.blixassociates.com/wp-content/ uploads/2011/03/No22.pdf (last accessed 12 December 2015).

76. Dando M. Bioterrorism: what is the real threat? Science and Technology Report No. 3. UK Global Health Policy Programme. London: The Nuffield Trust, 2005.

77. Kolavic SA, Kimura A, Simons SL, et al. An outbreak of Shigella dysenteriae Type 2 among laboratory workers due to intentional food contamination. JAMA. 1997; (278): 396-8.

78. Wheelis M, Casagrande R, Madden LV. Biological attack on agriculture: low-tech, high-impact bioterrorism. Bioscience. 2002; (52): 569-76.

79. Bourn J. The 2001 Outbreak of Foot and Mouth Disease. Report by the Comptroller and Auditor General, HC 939 Session 2001-2002. London, UK, National Audit Office. 2002. Available from: www.nao.gov.uk (last accessed 12 December 2015).

80. Meuwissen MPM, Van Boven M, Hagenaars TJ, et al. Predicting future costs of high-pathogenicity avian influenza epidemics: large versus small uncertainties. NJAS. 2006; (52): 195-205.

81. Schmitt K, Zacchia NA. Total decontamination cost of the anthrax letter attacks. Biosecur Bioterror. 2012; (10): 1-10.

82. Gibson DG1, Glass JI, Lartigue C, Noskov VN, Chuang RY, Algire MA, et al. Creation of a bacterial cell controlled by a chemically synthesized genome. Science. 2010 Jul 2; 329 (5987): 52-6. DOI: 10.1126/science.1190719.

83. Gibson DG, Venter JC. Synthetic biology: Construction of a 
yeast chromosome. Nature. 2014 May 8; 509 (7499): 168-9. DOI: 10.1038/509168a.

84. Hutchison CA, Chuang RY, Noskov VN, Assad-Garcia N, Deerinck $\mathrm{TJ}$, Ellisman $\mathrm{MH}$, et al. Design and synthesis of a minimal bacterial genome. Science. 2016 Mar 25; 351 (6280): aad6253. DOI: 10.1126/science.aad6253.

85. Boles KS, Kannan K, Gill J, Felderman M, Gouvis H, Hubby B, et al. Digital-to-biological converter for on-demand production of biologics. Nature Biotechnology. 2017; (35): 672-5 